\title{
Centralized PROCEssing OF
}

\section{CONTACT-HANDLED TRU WASTE}

\section{FEASIBILITY ANALYSIS}

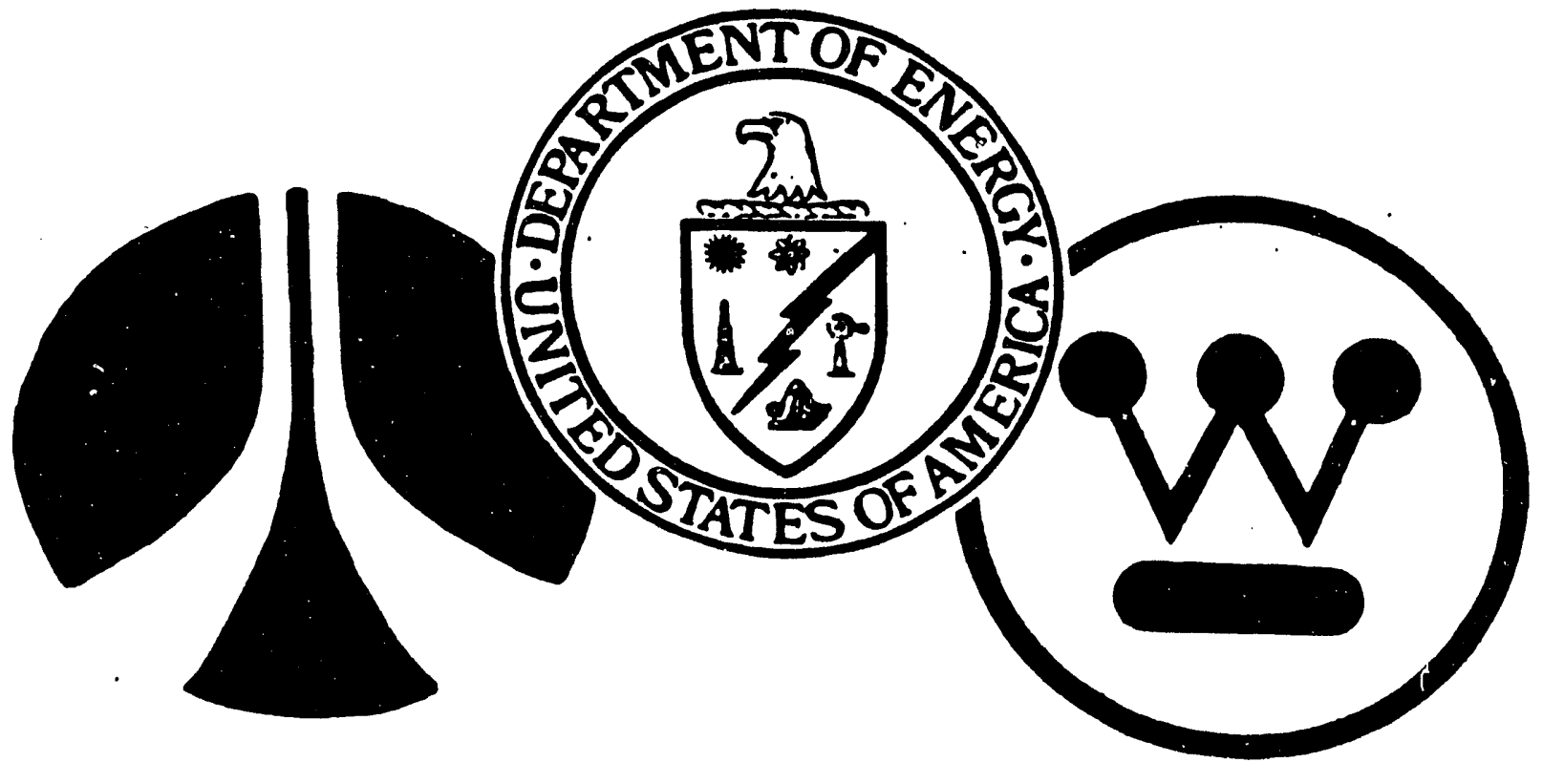

DEPARTMENT OF ENERGY

ROCKWELL INTERNATIONAL

WESTINGHOUSE

JOINT INTEGRATION OFFICE

ALBUQUERQUE, N.M.

\section{DECEMBER 1986}




\section{DISCLAIMER}

This report was prepared as an account of work sponsored by an agency of the United States Government. Neither the United States Government nor any agency thereof, nor any of their employees, makes any warranty, express or implied, or assumes any legal liability or responsibility for the accuracy, completeness, or usefulness of any information, apparatus, product, or process disclosed, or represents that its use would not infringe privately owned rights. Reference herein to any specific commercial product, process, or service by trade name, trademark, manufacturer, or otherwise, does not necessarily constitute or imply its endorsement, recommendation, or favoring by the United States Government or any agency thereof. The views and opinions of authors expressed herein do not necessarily state or reflect those of the United States Government or any agency thereof.

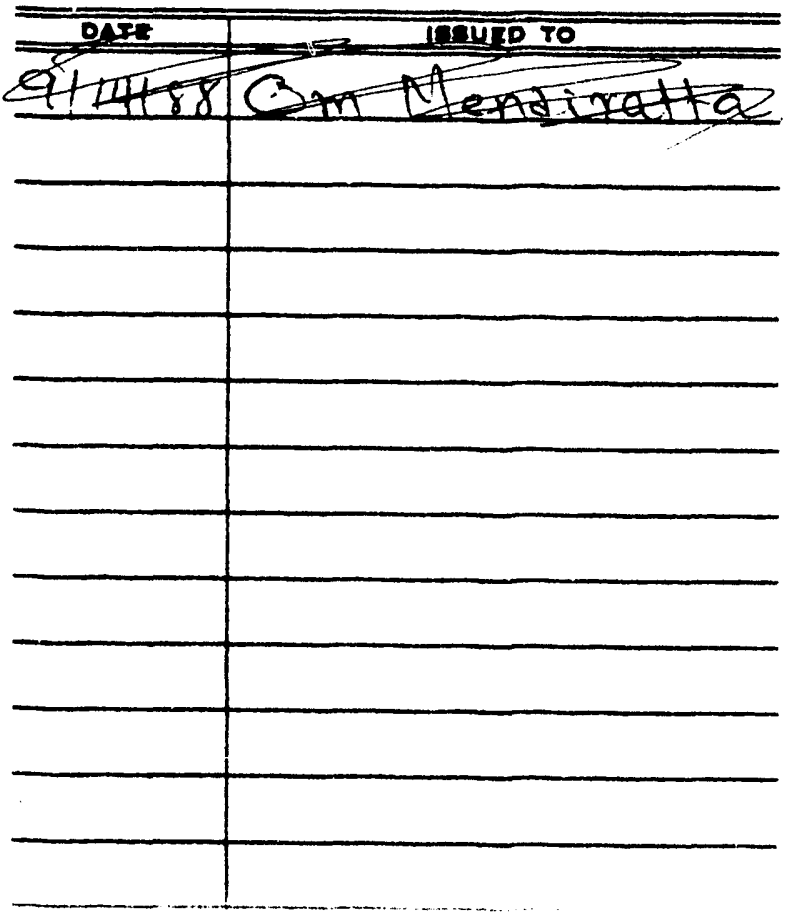


DOE/JIO--011

DE92 000883

TRU WASTE MANAGEMENT PROGRAM

CENTRALIZED PROCESSING OF CONTACT-HANDLED TRU WASTE

FEASIBILITY ANALYSIS

\author{
Prepared By \\ Joint Integration Office \\ $F \cap R$ \\ DEPARTMENT OF ENERGY WORKING GROUP \\ S. P. Mathur, DOE/HQ - Chairman \\ Members \\ E. K. Hunter, Department of Energy - Idaho \\ N. Karagianes, Department of Energy - Richland Operations
}

D. H. Reaulieu, Department of Energy - Albuquerque Operations

J. A. D'Ambrosia, Department of Energy - Savannah River Operations

December 1986

\title{
MASTER
}

DISTRIBUTION OF THIS DOCUMENT IS UN

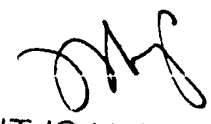




\section{EXECUTIVE SUMMARY}

Page

I. INTRODUCTION 3

II. APPROACH 4

III. DISCUSSION OF SCENARIOS 6

IV. TRANSPORTATION OPTIONS

V. SUMMARY OF COST ESTIMATES 11

VI. INSTITUTIONAL ISSUES 15

VII. FINDINGS AND RECOMMENDATIONS 17

$\begin{array}{ll}\text { APPENDICIES } & 18\end{array}$

APPENDIX A: PREPP Waste Evaluations -

APPENDIX B: Hanford and Savannah River Plant TRU Waste Volumes

APPENDIX C: Transportation Costs

APPENDIX D: Hanford and Savannah River Plant Facility Descriptions

APPENIX E: Hanford and Savannah River Plant Facility Costs

APPENDIX F: Independant Review Committee Comments to Final Draft

APPENDIX G: DOE Savannah River Comments to Final Draft

APPENDIX H: DOE Hanford Comments to Final Draft

APPENIIX I: DOE Idaho Comments to Final Draft 
EXECUTIVE SUMMARY

The Cost/Schedule Optimaization Study Report, October 1985, briefly investigated various scenarios for managing $\mathrm{CH}-\mathrm{TRU}$ wastes and recommended actions that have cost saving potential. The first scenario in the Report deals with centralized versus decentralized waste processing facilities. The Report concluded that if all CH-TRU wastes were processed at the Idaho, Stored Waste Examination Pilot Plant (SWEPP) and Process Experimental Pilot Plant (PREPP), instead of processing at proposed Richland Waste Receiving and Processing Facility (WRAP) and Savannah River Transuranic Waste Facility (TWF), then a potential cost saving of over $\$ 88$ million could be replized.

In December 1985, a Department of "Energy (DOE) Working Group (DWG) was organized with the charter to study this scenario in detail, addressing all institutional, technical, health and safety, and personnel exposure issues associated with centralized versus decentralized processing of $\mathrm{CH}-$ TRU wastes. This report is the result of the study conducted by the DWG.

After compilation and evaluation of the data from each site, used in this study, conflicting comments were received from the DWG membership regarding reported costs and the significance of certain institutional issues. Since resolution of all comments seemed impossible and the membership agreed that resolution would not alter the overall results, it was decided by the DWG chairman to issue the report as is. Therefore, the cost figures, waste volumes and some of the 
alternatives have not been modified to express the latest available information.

As a result of this study it has been determined that the original estimate of potential cost saving of over $\$ 88$ million failed to account for the need for shipping preparation facilities at both Hanford and Savannah River and other costs associated with centralized processing. Based on the approach taken, costs for centralization may actually be higher than decentralization.

The study was able to show that the concept of centralized processing is indeed technically feasible, however, due to institutional constraints, centralized processing of TRU waste is not economically feasible. The maior constraint is the inability of Hanford site and SRP to ship the waste without assaying, which will cost approximately $\$ 30$ Million per site. The resolution of some of these institutional issues is beyond the ability of the DWG members because the decisions will have to be made at very high management ievels.

Therefore, it is the conclusion of this study that decentralized processing is the most favorable programmatic direction and that the activities leading to the construction and operation of the WRAP and TWF facilities should resume as soon as practical. 
I. INTRODUCTION

In Fiscal Year 1985 a cost/schedule optimization study was conducted to ensure that the Defense Transuranic (TRU) Waste Program (DTWP) goals and plans are optimized from a cost and schedule aspect (Reference: DOE-JIn 004, "TRU Waste Management Program Cost/Schedule Optimization Analysis," October 1985). One of the major findings of the study was that centralized processing of Contact-Handled (CH) TRU waste at the Idaho National Engineering Laboratory (INEL) held promise for reducing system cost. This approach would call for shipping all Hanford and Savannah River Plant (SRP) waste to INEL for processing in the Stored Waste Examination Pilot Plant (SWEPP) and the Process Experimental Pilot Plant (PREPP) facilites. The $\$ 88$ Million savings estimated by the study, resulted from not having to construct Hanford's Waste Receiving and Processing (WRAP) Facility and SRP's Transuranic Waste Facility (TWF) for processing waste at those sites. However, in conjunction with the analysis it was recommended that technical and institutional uncertainties receive further evaluation before making any program direction changes.

In December of 1985 a Department of Energy Working Group (DWG) was formed with the responsibility of compieting assessing the feasibility of utilizing the INEL facilities for centralized processing. This DWG both expanded on the evaluation of the technical and institutional uncertainties identified in the Cost/Optimization Analysis and provided a more detailed cost analysis. Although the costs are strictly a "rough order of magnitude," the results of this assessment now provide the Department of Energy-Head Quarters (DOE-HQ) with 
sufficient information with which it can make a determination of the most cost efficient program for the processing of $\mathrm{CH}-\mathrm{TRU}$ wastes.

\section{APPROACH}

Four major scenarios for processing CH-TRU waste were evaluated in detail. They are;

- Scenario 1 Base Case: Process waste at all three sites; INEL waste at INEL in SWEPP and PREPP, Hanford waste in the planned WRAP Facility, SRP waste in the planned TKF.

- Scenario 2 Transport and process all Hanford and SRP waste at the INEL SWEPP/PREPP facilities.

- Scenario 3 Transport and process all Hanford waste at the INEL SWEPP/PREPP facilities, SRP waste to be processed in TWF.

- Scenario 4 Transport and process all SRP waste at the INEL SWEPP/PREPP facilities, Hanford waste to be processed in WRAP facility.

The preliminary step in conducting the study was first to determine if the INEL SWFPP/PREPP facilities (including the planned upgrades; SWEPP-II/ PREPP-II), as designed and constructed, were suitable for processing SRP and Hanford wastes. This was necessary as SRP waste contains large quantities of $\mathrm{Pu}-238$ and due to the general differences between INEL wastes and those at SRP and Hanford. Additionally, it had to be determined if SWEPP/PREPP has the necessary excess capacity to handle the added waste volume. If SWEPP/PREPP were unable to handle the waste one or more of the options might have been precluded. However, INEL determined that there would be no operational difficulties in processing either the SRP or Hanford wastes provided the wastes could be shipped to Idaho (some Hanford waste boxes are too large for SWEPP/PREPP, however they will require 
size reduction to allow for shipping and processing at INEL.) Appendix A contains a copy of the PREPP waste evaluations.

During the second step of the study, SRP and Hanford sites compiled their requirements and costs for any facilities or equipment necessary to support shipping and processing of the wastes at INEL. These requirements included needs for container venting/purging, overpacking, NDA/NDE, shipping and size reduction at SRP and Hanford in addition to the needs for upgrades or improvements to SWEPP/PREPP. Additionally, a breakdown of SRP and Hanford wastes, based on which waste could be transported in what type of shipping container, was made to assist in the later shipping cost calculations.

During the study it was determined that small modifications to the original scenarios might provide viable alternatives. These modifications are detailed, along with a full description of the major scenarios, in the section III.

Each new scenario was broken down to determine an overall rough order of magnitude system costs (facility construction and operation, shipping, etc.) for comparison to the system costs for the base case scenario.

A listing of pertinent institutional issues related to centralized processing is included in this report. These issues were provided by the DWG members, based on the procedures established at the various operational offices. 
III. DISCUSSION OF SCENARIOS

Scenario 1 (Process Waste at all Three Sites)

This "base case" scenario reflects the strategy in the Defense Waste Management PIan and calls for the construction of the TWF at SRP and the WRAP Facility at Hanford, in addition to the al ready constructed SWEPP/PREPP facilities at INEL. Each of the three major sites will process waste on-site, so it can be disposed of either as LLW at their own facility or certified and shipped to the Waste Isolation Pilot Plant (WIPP) for permanent storage.

Scenario 2 (Centralized Processing of All Waste)

This scenario calls for shipping all SRP and Hanford non-certifiable TRU waste to INEL for processing in SWEPP/PREPP. SRP and Hanford will be responsible for providing what ever minimal facilities are necessary to retrieve waste and perform the minimum actions necessary to ship the waste to INEL for processing. Two major options to this scenario are available; a) to not provide assay capability for the stored waste and b) to provide assay capability for the stored waste.

Option a;

Without assay capability all stored waste will be retrieved, the containers will be vented/purged of explosive gases, overpacked if container integrity is suspect and shipped to INEL for processing. In addition, the non certifiable portion of newly-generated wastes will be sent to INEL for processing.

Option b;

With assay capability on stored waste, the stored waste will be 
retrieved, the containers will be vented/purged of explosive gases, assayed to separate the TRU and LLW constituents, overpacked if container integrity is suspect and shipped to INEL for processing. As before, the non certifiable portion of newly-generated wastes will be sent to INEL for processing.

The difference between not assaying and assaying lies in the separation of the TRU waste from the LLW. Therefore, each site would bury it's own LLW and save on shipping costs. However, assaying increases the site facility and operating costs significantly. There are no differences in the handling of newly generated wastes.

A further modification applicable to this scenario is the different options that might be available for handling of the Hanford "size reduction" waste (i.e. waste containers too large to ship to INEL without size reduction.) Options of both size reducing the waste and shipping it to INEL (Options a \& b) and utilizing Greater Confinement Disposal (GCD) practices on the waste without size reduction (Options c \& d) were examined.

Scenario 3 (Only Hanford Waste to INEL)

This scenario is a combination of Scenarios 1 and 2 , it calls for construction of TWF at SRP in addition to the already constructed SWEPP/PREPP facilities at INEL. SRP will maintain responsibility for on-site processing, so all waste can be disposed of either as LLW at their own facility or certified and shipped to the Waste Isolation Pilot Plant (WIPP) for permanent storage. Hanford will be responsible for providing minimal facilities to retrieve waste and perform the 
minimum actions necessary to ship the waste to INEL for processing. All modifications to Scenario 2 also apply to this scenario.

Scenario 4 (Oniy SRP Waste to INEL)

This scenario is a combination of Scenarios 1 and 2 but is opposite to Scenario 3; it calls for construction of WRAP at Hanford in addition to the already constructed SWEPP/PREPP facilities at INEL. Hanford will maintain responsibility for processing in-house so all waste can be disposed of either as LLW at their own facility or certified and shipped to the Waste Isolation Pilot Plant (WIPP) for permanent storage. SRP will be responsible for providing minimal facilities to retrieve waste and perform the minimum actions necessary to ship the waste to INEL for processing. The without assay/with assay modifications to Scenario 2 also apply to this scenario.

\section{TRANSPORTATION OPTIONS}

Three shipping containers were identified for possible use in shipping waste from Hanford and SRP to INEL, the TRUPACT, ATMX railcar and Super Tiger.

USABLE INTERIOR DIMENSIONS OF SHIPPING CONTAINERS

$\begin{array}{lccc} & \text { Length } & \text { Width } & \text { Height } \\ \text { TRUPACT } & 230^{\prime \prime} & 74^{\prime \prime} & 86^{\prime \prime} \\ \text { TRUPACT-II } & 218^{\prime \prime} & 80^{\prime \prime} & 80^{\prime \prime} \\ \text { ATMX Railcar } & 264^{\prime \prime} & 105^{\prime \prime} & 105^{\prime \prime} \\ \text { Super Tiger } & 172^{\prime \prime} & 76^{\prime \prime} & 76^{\prime \prime}\end{array}$

A11 three containers require the inner waste packages to meet DOT Type A requirements. Consequently waste packages retrieved from interim storage facilities will have to be inspected to verify that the container meets these requirements. If the retrieved package does 
not meet the requirements, then it will require overpacking in a Type A container.

Specific requirements for each package are:

TP.UPACT - The TRUPACT-I SARP is in draft form. Consequently the requirements that will be imposed when the Certificate of Compliance $(C O C)$ is issued can only be projected. Some sections of the SARP (undated draft) infer that the requirements of the Super Tiger with respect to waste form and packaging will be applicable to the TRUPACT. If this is the case, a very small percentage of the retrieved interim stored waste packages can be shipped in the TRUPACT.

Other sections in Chapter 1 of the SARP imply some lesser criteria:

0 waste to be bagged in 5 to $12 \mathrm{mil}$ thick polyethelene, PVC or equivalent material

- bagged waste to be in lined waste containers ( 80 to 90 mil rigid iners)

- particulate content same as WIPP WAC

- nonliquid form (WIPP Waste Acceptance Criteria (WAC) permits residual 1 iquid)

- gas generation per DOT Regulations 49CFR173.24(a)(3)

- hard waste to have coating to fix contaminants or decontaminated

- sharp edges or pointed features blunted

Either of the above interpretations of the SARP will restrict the amount of waste certified to the WIPP WAC. A significantly smaller percentage of the uncertified waste retrieved from interim storage could be shipped in the TRUPACT. 
ATMX - The ATMX-600 SARP provides a general description of waste forms that must be contained within the Rocky Flats Plant (RFP) waste packaging materials. If the waste container can be inspected to verify that it still meets DOT-7A requirements and were procured to the RFP or Mound Laboratory specifications, then the waste package should be able to be shipped in the ATMX-600 railcar without overpacking. However, if the waste package does not meat the DOT 7A requirements it will require overpacking.

Super Tiger - The requirements for packaging waste to be shipped in the Super Tiger are very restrictive. If the waste were packaged to meet these requirements it would be either less than $100 \mathrm{nCi} / \mathrm{g}$ (non-transuranic) or meet the WIPP-WAC criteria (thereby making shipment to INEL unnecessary.)

In short, the Super Tiger should not be considered for shipping the subject waste.

Current status of the three containers is:

TRUPACT-I SARP is currently being written. It must be reviewed and approved by DOE/AL and DOE/HQ before DOE/HQ will issue a COC. Receipt of the COC for TRUPACT-I is not anticipated before the end of 1986. A COC for TRUPACT-II is currently scheduled for October 1987.

Shipments in the ATMX railcars is authorized by Special Permit No. 5948. When the TRUPACT COC is obtained it is possible that this special permit would no longer be renewed. The current permit authorizes shipments only from Mound and RFP.

Shipments in the Super Tiger are authorized under NRC Certificate Number 6400 . The package identification number is USA/6400/B()F.

Further evaluation for this study assumes only the TRUPACT and ATMX railcar are acceptable shipping containers. In computing shipping costs for these containers (Appendix B) it was necessary to assume the 
waste packages would not require overpacking, although a great number will. This assumption was made because it is unknown how much of the waste would require the overpacks and how much wolild not. Therefore, the reported shipping costs will be lower than the actual shipping costs because expenses for the overpacks themselves and the necessary additional shipments (packing efficiencies will be reduced.) The difference in cost is not considered significant enough t.o impact the decision of this study.

\section{SUMMARY OF COST ESTIMATES}

A comparison chart of total system costs for each scenario evaluated by this study is shown on the following page. The cost figures are rough order of magnitude only and error bands may increase the actual cost by as much as $50 \%$ in some scenarios. The data used in computing the costs may be found in the appendicies of the report.

Scenario 1: Process Waste at all Three Sites

TOTAL COST \$498M.

This is the base case scenario.

\section{Scenario 2: Centralized Processing of All Waste}

Option a; No assay capibility, size reduce Hanford oversize boxes TOTAL COST \$448M.

Shipping all waste to INEL for processing (without assay capability on stored waste) has a positive cost impact when compared to the base scenario. Savings estimated at \$50Milition. 
TOTAL SYSTE. COST FOR EACH SCEMARIO (MILLIONS OF DOLLARS)

DIFFERENCE SITE SITE SITE INEL ADD LLN VERIS

SCEMARIO

FACILITY OPERATING SHIPPIIG PROCESSIRG BURIAL TOTAL SCENARIO 1

1) Process at all

three sites

--Hanford

--SRP

COSTS COSTS COSTS COSTS

COSTS COSTS $(1)=$ LOST

2) Process all vaste

at INEL

a) No site assay

$\$ 77 \quad \$ 274$

$\$ 0$

80

$\$ 0 \$ \$ 498$

$n / a$

- -Hanford

$\$ 95$

$\$ 403$

80

$\begin{array}{llllll}\$ 46 & \$ 120 & \$ 0 & \$ 0 & \$ 0 & \$ 166 \\ \$ 49 & \$ 283 & \$ 0 & \$ 0 & \$ 0 & \$ 332\end{array}$

- -SRP

$835 \quad 840$

$\$ 9$

$\begin{array}{lll}\$ 83 & \$ 6 & \$ 447 \\ \$ 41 & \$ 2 & \$ 123 \\ \$ 41 & \$ 4 & \$ 324\end{array}$

$\$ 51$

$\$ 42 \$ 234$

$$
85
$$

$\$ 41$

b) Site assay

- Hanford

$\$ 86 \quad \$ 329$

95

$\$ 83 \quad 80 \quad 8502$

--SRP

$\$ 43 \quad \$ 96$

84

$\$ 4180 \quad 8183$

$843 \quad \$ 234$

81

841

$80 \quad 8319$

c) GCD Hanf oversize, no assay

- Hanford

$\begin{array}{lr}863 & \$ 254 \\ \$ 21 & \$ 20\end{array}$

88

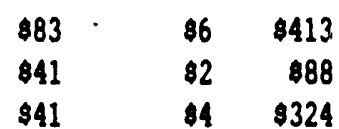

$\$ 85$

- -SRP

$\$ 42$

$\$ 234$

84

$\$ 41$

d) GCD hanf over-

size, no assay

- Hanford

$\$ 72$

84

$\begin{array}{lll}\$ 83 & \$ 0 & \$ 468 \\ \$ 41 & \$ 0 & \$ 149 \\ \$ 41 & \$ 0 & \$ 319\end{array}$

$\$ 30$

- -SRP

$829 \quad 876$

83

841

8319

3) Process only Hanford

vaste at INEL

a) No site assay

- Hanford

$\$ 84 \quad \$ 323$

$835 \quad 840$

85

$\begin{array}{rll}\$ 83 & \$ 2 & \$ 496 \\ \$ 83 & \$ 2 & \$ 164 \\ \$ 0 & \$ 0 & \$ 332\end{array}$

$\$ 2$

- SRP

849

$\$ 283$

80

$892 \quad 8379$

b) Site assay

--Hanford

$843 \quad 896$

84

\section{3}

883

$80 \quad 8556$

$\$ 0 \quad \$ 224$

--SRP

$\$ 49 \quad \$ 283$

$\$ 4$

80

$80 \quad \$ 332$

c) GCD lanf oversize, no assay

--Banford

$\$ 70 \quad \$ 303$

$\$ 21 \quad 820$

84
84

$\$ 83$

$\begin{array}{ll}\$ 2 & \$ 462 \\ \$ 2 & 8130 \\ \$ 0 & \$ 332\end{array}$

$\$ 36$

--SRP

$\$ 49$

$\$ 283$

$\$ 0$

883

$\$ 0$

$\$ 332$

d) GCD Hanf oversize, assay

- Hanford

$\$ 78 \quad \$ 359$

83

$\begin{array}{rll}883 & 80 & 8522 \\ 883 & 80 & 8190 \\ 80 & 80 & \$ 332\end{array}$

- -SRP

$\begin{array}{lr}\$ 29 & \$ 76 \\ \$ 49 & \$ 283\end{array}$

83

83

$\$ 0 \$ 332$

4) Process only SRP vaste at INEL

a) lio site assay

- hanford

$\begin{array}{lllrll}888 & \$ 354 & \$ 4 & 883 & 84 & 8532 \\ 846 & \$ 120 & 80 & 80 & 80 & 8166 \\ 842 & \$ 234 & 84 & 883 & \$ 4 & 8366 \\ 889 & \$ 354 & 81 & 883 & \$ 0 & 8527 \\ 846 & \$ 120 & 80 & 80 & 80 & 8166 \\ 843 & 8234 & 81 & 883 & 80 & 8361\end{array}$

(834)

- SRP

b) Site assay

--Hanford

--SRP

$843 \quad 8234$

80
81

883

8166
8361

(84)

85

30


Option b; Assay capibility, size reduce Hanford oversize boxes TOTAL COST \$502M.

Shipping of only TRU waste to INEL for processing (with assay capability on stored waste) has essentially the same cost as the base case.

Option c; No assay capibility, GCD Hanford oversize boxes TOTAL COST \$413M.

Utilizing greater confinement disposal on Hanford waste that will not fit in the $A T M X$ (Vs, size reduction) and shipping all remaining waste to INEL for processing (without assay capability on stored waste) has a positive cost impact when compared to the base case. Savings estimated at \$85Million.

Option d; Assay capibility, GCD Hanford oversize boxes TOTAL COST \$468M.

Utilizing greater confinement disposal on Hanford waste that will not fit in the ATMX (vs. size reduction) and shipping only TRU waste to INEL for processing (with assay capability on stored waste) has a positive cost impact when compared to the base case. Savings estimated at \$30Million.

Scenario 3: Only Hanford Waste to INEL Option a; No assay capibility, size reduce Hanford oversize boxes TOTAL COST \$497M.

Shipping all Hanford waste to INEL for processing (without assay capability on stored waste) and proceeding with TWF at SRP has essentially the same cost as the base case. 
Option b; Assay capibility, size reduce Hanford oversize boxes TOTAL COST \$556M.

Shipping of only Hanford TRU waste to INEL for processing (with assay capability on stored waste) and proceeding with TWF at SRP has a negative cost impact when compared to the base scenario. Added cost is estimated at \$58Milion. Primarily due to Hanford accepting the full added SWEPP/PREPP costs instead of splitting them with SRP (i.e., SWEPP and PREPP will require one added shift to handle one or both of the other sites waste, therefore, if only one site ships to INEL for processing added costs at SWEPP/PREPP are the same if both sites ship to INEL for processing.)

Option c; No assay capibility, GCD Hanford oversize boxes TOTAL COST \$462M. Utilizing greater confinement disposal on Hanford waste that will not fit in the ATMX (vs. size reduction) and shipping all remaining Hanford waste to INEL for processing (without assay capability on stored waste) and proceeding with TWF at SRP has a positive cost impact when compared to the base case. Savings estimated at \$36Million.

Option d; Assay capibility, GCD Hanford oversize waste TOTAL COST \$522M.

Utilizing greater confinement disposal on Hanford waste that will not fit in the ATMX (vs. size reduction) and shipping only TRU Hanford waste to INEL for processing (with assay capability on stored waste) and proceeding with TWF at SRP has a negative cost impact when compared to the base case. Added cost is estimated at \$24Million. 
Scenario 4 (Only SRP Waste to INEL)

Option a: No assay capibility

TOTAL COST \$532M.

Shipping all SRP waste to INEL for processing (without assay capability on stored waste) and proceeding with WRAP at Hanford is cost detrimental compared to the base scenario. Added cost estimated at \$34Million. Primarily due to SRP accepting the full added SWEPP/PREPP costs instead of splitting them with Hanford.

Option b: Assay capibility

TOTAL COST \$526M.

Shipping of only Hanford TRU waste to INEL for processing (with assay capability on stored waste) and proceeding with WRAP at Hanford is cost detrimental compared to the base scenario. Added cost estimated at \$29Million. Primarily due to SRP accepting the full added SWEPP/PREPP costs instead of splitting them with Hanford.

VI. INSTITUTIONAL ISSUES

There exists numerous institutional issues that should be addressed while forming any decision to change the current program direction for processing TRU waste. It is beyond the scope of this study to analyse each issue and make a determination as to their validity. However, those issues identified during the study are presented below for consideration by DOE/HQ during the decision process. General Issues:

- Cost estimates presented are rough order of magnitude only and may increase as much as $50 \%$. 
- What are the chances of Congress approving two facilities which will cost more than \$40Million each? As a correlary, both sites will still need capital facilities even with centralized processing for preparing waste for shipment to INEL.

- What is the potential impact on the program if centralized processing at INEL is pursued and the reliability and capacity of the SWEPP and PREPP fail to meet projections?

- How will the State of Idaho react to the shipment of large quantities of TRU waste into their state for processing?

- If assay capability is not provided at Hanford and SRP what will the State of Idaho's reaction be to the burial of over 350,000 cubic feet of waste, waste that used to be called TRU and is now classified as LLW, in their state?

- Some Hanford boxes contain up to 1,000 grams of TRU which may exceed the PREPP incinerator limits.

o Centralized processing is contrary to ALARA goals as it increases handling of waste.

- SWEPP and PREPP are not currently scheduled to handle classified waste such as that currently in storage at Hanford.

- What additional NEPA documentation is required to implement the concept of centralized processing?

- The Greater Confinement Disposal of the large boxes at Hanford may not be acceptable to the State of Washington if any alternative except "in-place stabilization and disposal" is chosen.

Transportation Issues:

- Will DOT allow shipments of materials that may not have accurate or complete inventories of contents?

- Considerations such as routing, pre-notification, emergency response, public liability, etc., should not be significantly different than those for WIPP certified waste shipments in TRUPACT. The term "uncertified" should be well explained so that it does not connote that the waste form is "unknown."

- Rail shipments are regulated by federal agencies and are conducted on private right-of-ways. Therefore, such shipments would involve less state oversight, but not less concern with issues such as routing and emergency response.

- Regarding use of the ATMX railcar;

Will Washington, Idaho, South Carolina, and all states in between, allow use of the ATHX on a long term basis for shipments that might be considered to be less than critical to the national defense? 
The ATMX is not a certified Type B packaging and is operating under a DOT exemption. Although these cars have a good track record, states and the media could see this as a public health and safety issue, particularly if shipments have to pass through high population areas.

The ATMX has the advantage of operating on private right-of-ways and some of the problems associated with highway travel do not exist for this mode. Although the states recognize that they have less regulatory control over rail than highway, they have almost the same institutional concerns as for highway, and are very concerned about the condition of roadbeds and track.

It would be difficult to rationalize use of the ATMX when the "official" packaging for TRU waste shipments is TRUPACT. Use of ATMX could be viewed as an admission that TRUPACT is not suitable for this application.

Regarding use of the TRUPACT;

When TRUPACT is certified as a Type B packaging, it represents the best option for transporting uncertified $\mathrm{CH}$-TRU waste since the "uncertified packaging" argument is no longer valid.

Assuming that TRUPACT is certified and the waste forms comply with the COC content restrictions, shipments should not present any incremental institutional challenges above and beyond those for TRUPACT shipments to WIPP.

- In summary, use of certified packagings will present lesser institutional challenges than the use of uncertified packagings. However, predicting what the actual institutional implications of shipping uncertified waste in either of these packagings cannot be predicted with any certainty.

VII. FINDINGS AND RECOMMENDATIONS

The overall findings of this study are:

- CH-TRU waste from the Hanford Site and Savannah River Plant can be processed at INEL's Stored Waste Examination Pilot Plant and Process Experimental Pilot Plant, if these wastes can be shipped.

- Operating procedures at the Hanford Site and at Savannah River plant will require that the waste be examined/assayed prior to shipment to INEL, which will offset potential cost savings from centralized processing of the wastes.

The overall recommendation of this study is:

The Waste Receiving and Processing Facility at the Hanford site and the Transuranic Waste Facility at the Savannah River Plant should be constructed and operated. 


\section{APPENDICIES}

APPENDIX A: PREPP Waste Evaluations

APPENDIX B: Hanford and Savannah River Plant TRU Waste Volumes

APPENDIX C: Transportation Costs

APPENDIX D: Hanford and Savannah River Plant Facility Descriptions

APPENDIX E: Hanford and Savannah River Plant Facility Costs

APPENDIX F: Independant Review Committee Comments to Final Draft

APPENDIX G: DOE Savannah River Comments to Final Draft

APPENDIX H: DOE Hanford Comments to Final Draft

APPENDIX I: DOE Idaho Comments to Final Draft 
APPENDIX A: PREPP WASTE EVALUATIONS

January 20.1800

EAFP

Wenterelunten

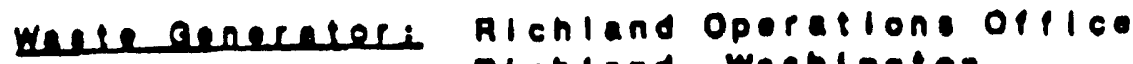

Alchland. Wastington

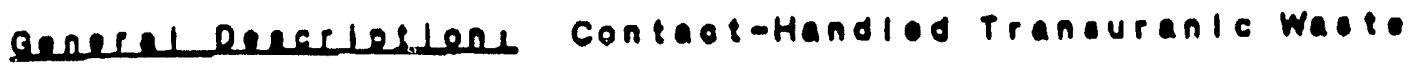

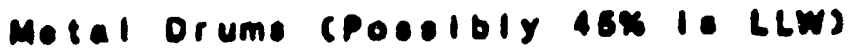

- Combustibles ro-son or the 80.000 drume

- Noneambusibler 20-sox of the tolat volume

- Secupity Claseliteds - 1000 drumo

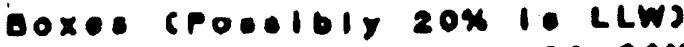

- Nonoombuetible: 80-00x of the 7500 ouble metere

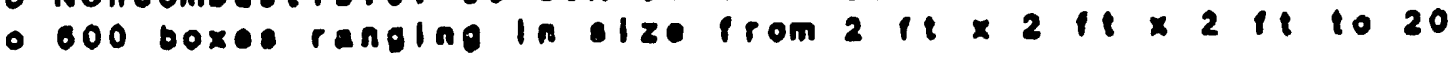
it $\times 0$ it $\times 13$ it

\section{Exulunteat}

1. Typos and Quantltios or 1008000:

oefence related wasto contalning epproximately $400 \mathrm{~kg}$ or transuranium nuolide.

The lootople content of this wate lo elmitar to thet gonerated by hooky flate whioh was uood ac the basio lor the pAEPp desion consequentiy. no probleme ero antlelpatod.

2. 8urtace Radiation lovelo and curle contents

- Alpha Radionctivitys $40.000 \mathrm{Cl}$

- Exterior ourtace doec: $1200 \mathrm{mr} / \mathrm{hr}$

A. ouming the $16.000 \mathrm{Ci}$ of Alphe radioactivity was ovoniy dietributed in ene transuranic waste $627.3 \times$ ot the totels. thle oquates to appoximately o ci per cuble meter or -0.2 ci per cuble it. Thle level of alpha activity ie no hloher inan that found in the Rocky flete waste curpontiy btored at the INEL and ocheduled to be proceesed in PREPP.

The 200 mrinr exterlor surtace dose Ilmlt meete ine requirements for handing the weste conteinero within PAEPP.

3. Waste Container 81ze:

30 oulion Meral Drume

66 aetion Metal Drume

80 celion Metel orume

ool ia steci bexes

concrele Boxer

Fiberglese relntorced plywood boxes 
All drume Identilied above and boxed emalier inon 00

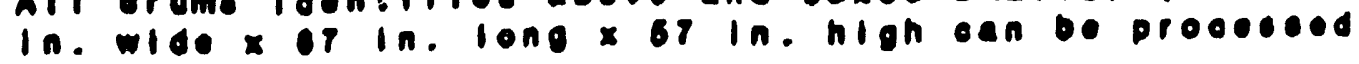
in PREPP.

4. Waste Contelner Welght: The meximum contalaep weleht

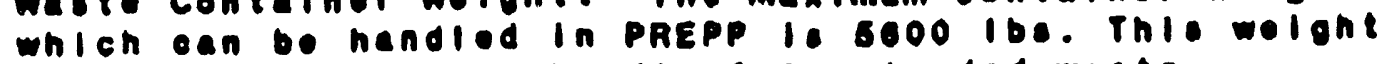
IImit le adequete to handie fuliy loadod waete eontelnere ldentified in s above.

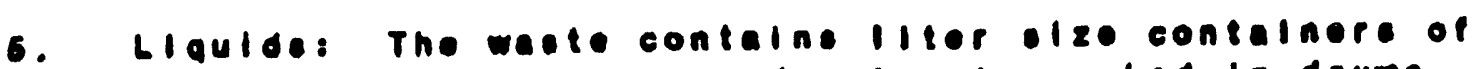
olis. cleaning egents. and colvents pooked í arume with aboorbont. PAEPp wa desioned to proocos drumelooxer whion contala one i gelion (8.7 IIters quantilies of liameble liquide. orumeloexes whioh contaln more than 1 galion cannot ourrentiy bo prooescod at pREPP. However. due to the exisiting need to proces inel wate containing hioner quantitios of ligulde. work lo ourrently underway to make tho

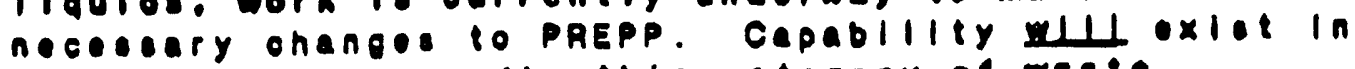
the outyeare to hendio inte octegory of westo.

6. Neture of waste: Tho oenoral nature of tho wasto appore elmilar to ino hocky Fiate waste currentiy otored et ine INEL. 


\section{eafee \\ were Exelunten}

Westereneceteri savannan Rlver Operaplons ortloe Alken. soulh Carolina

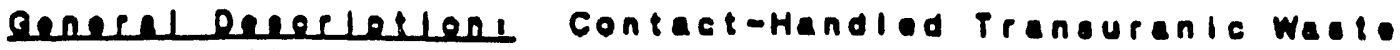
110.848180 of waele by 1001

\section{Evelunters}

1. Types and Ouantlitec of lootopoes

- Pu-288 1. 60 volume percent of the total. Most of inle weste le contalined in drume. Twenty peroent of ineoe drums oonlein betweon 10 and 32 of pu-288. It le coumed thet the remalining waete contelins lower quantilies of Pu-zas.

- Pu-230 (trom depense rolated proececes) Io oontelined in the ramainine cox of the wasto.

The loregolng analyol lo beed on the data and discuesion of Chapter 28 of the plutonlum Hendbook. (Rol. I) and oulde For Fabrleating and. Handling CF-262 sources (her. 2 ).

Asouming that a drum contelno waste of a compactible nature. but has not been compacted. A drum should weloh 260 to 300 pounds. Theretore. the denelty of the meterlat in the drums lo aseumed to be in the range of 0.0 to 0.7 g/ce. With 30 grams of pu-288 in cach drum, the curie content le calculated to bo 622 curiestorum and the curlo deneliy le calculated to be $4.8 \times 10^{-0}$ $103.8 \times 10-0$ Cilo. From Reference 1. Pg. 861 . and baced on a curle denelty or l curleloram the surtece doserale due to gammes and $x$-raye for unelad meterlel conteining pu-238 l. calculatod to be 000 Rade/hr. At the ebove-calculeted denstites the doseretes at the ourpace of the wasto are calculated to bo 3.7 to 4.4 Radelhr. Al the urtace of DOT ITH orum. with a - ldowall thleknese of 0.06 inches. Inle doserate would be ettenuated to $0.1 \mathrm{mr} / \mathrm{hr}$ due to the attenuation of ine 18 kev $\gamma$ and $x$-ray component.

The neutron emiesion rate token trom Table 26.2. po.

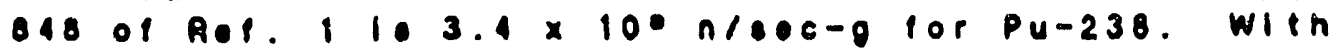
- drum contalining 30 grame of thie lootope the neutron generation rete would be $1.02 \times 10^{\circ} \mathrm{n} /$ cec.

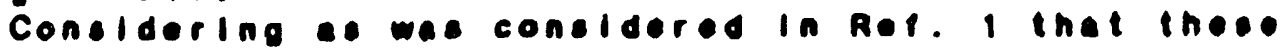
noutrone ere inermal neutrons. the maximum ncutron liuence at the ourtace of the drum le calculated to be - $n / \mathrm{cm}$ eloec whlch olves the noutron doserete to be 
I melhr. Ap e chock of thle velue. the methodology of Ref. 2 wee uned. Ref. 2. page o. etetee that at

1 meter Irom a 10-mililigram C1-252 cource.

Unshleldod Noutron Doec Equivelont Rete

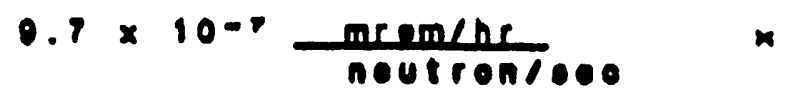

$2.3 \times 10$ ongution $10-a \operatorname{ernm}$

$2.2 \times 10^{0}$ mrom/hour.

Ratiolng thio value to the $1.0 \times 100$ nto genorated in ine drum and calculating the doecrate for a dietence or 1 i.. pether inan 1 meter. olves imrinr.

Therefore. from a redologlcal etandpolnt, handing drummed quantitlos of aRp Pu-230 waste la not expocted to opecte eny inordinate radiological probloms inat on not be handiod at the pRePp laolitiy. Although the celculations pertormed above were applieable to one drum conteining 30 grams or b20 curlpe of pu-2as. ino redologleal acesement lor materlal to be handied in the drum-lil area of phepp ere colimated to be poughis the same. With an ostimated conoolidation tactor of three for material in the drum-iili erea. the additon of concrote to tho wasto at this polntwill provide considerable seli-shlelding lor both neutrons and y and $x-r a y=$.

A. presentiy envisioned. the greasest rediologleal Impact to PREPp personnol l. wen to bo In the event of an operational upoet which roquires pereonnel ontry into the proces otream for maintenance. This condition would be handlod by an appropriate ALARA roviow and approprlately constructed and appeoved oelalled opereting procedure (Dopes.

2. Surtace Rediation Levolo ond curle content: - Aipha Redioctivity: 8ec liom l. above. - Exterlor curtece dose: $6200 \mathrm{mr} / \mathrm{nr}$

The 200 mrinr exterlor eurface dose limit mete the requiromente for handing the waste containers within PAEPP.

3. Waste contatner 81ze: All drums idontilied ebove and

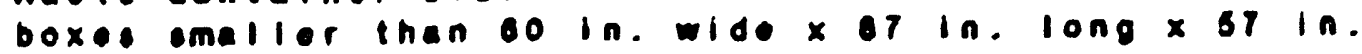
hion can bo proceoced in PAEPP. 
4. Wete Contalnor Welont: The maximum oontalner welont which can bo handiad in PAEPp le 5800 lbe. Thio weloht IImit le adequete to handie tully loaded waste contalinero ldentifled in above.

6. Llauldes No freo I lquida have boen lontified in the wate. Howerer. PREPp wae doeloned to procese drumelboxes which contain one isalion (a.7 liter) quantitles of liammable liqulda. Drumstboxes which contaln more inan i dalion cannot currentiy bo prococoed at paEpp. Howover. due to the exioting neod to procese INEL wate conicining hioner quantilies or l iqude. work lo currentiy underway to make the

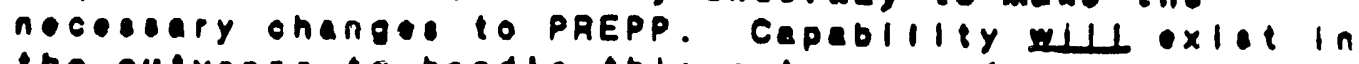
the outyeare to handie thite cetegory of waste.

- Nature of Wate: seventy peraent or the waete is cateoorlzod as "job oontrol waston which consicte of -lacs. entl-ce. blotter paper. oloves.eto. The remaining waste conslote or ludgos. HEPA IIItero.and other miscelianeous itoms. The general nature of ine wate eppece cimilar to the Rocky flets wasto currentiy ciored a the INEL that will be procesoodin PREPP. 
APPENDIX B: HANFORD AND ¿AVANNAH RIVER PLANT TRU WASTE VOLUMES

In order to evaluate facility requirements and costs for scenarios

2 - 4 Hanford and SRP waste inventories were separated into catagories

based on handling, shipping and processing requirements.

- Wastes shippable in the Transuranic Package Transporter

(TRUPACT), consisting of drums and smaller ( $\left.5^{\prime} \times 5^{\prime} \times 7^{\prime}\right)$

boxes. These wastes containers are processable in SWEPP and PREPP.

- Waste boxes too large for the TRUPACT but shippable in the ATMX. These boxes will be processable in SWEPP-II and PREPP - II.

- Waste boxes too large for the ATMX. These boxes will require size reduction prior to shipment.

Stored and Newly-Generated waste volumes and the handling catagory

breakdowns used in this study are shown on the following pages. 
TABLE B-1: HANFORD SITE TRU WASTE INUENTORIES

\begin{tabular}{|c|c|c|c|c|c|c|}
\hline \multirow[b]{2}{*}{ CLASSIFICATIOA } & \multicolumn{3}{|c|}{ STORED } & \multicolumn{3}{|c|}{ MENLY GENERATED } \\
\hline & VOLOAE & 1 DRUAS & BOXES & VOLUAE & DRUAS & IBOXES \\
\hline SUEPP/PREPP & 238,343 & 32,284 & 178 & 609,098 & 86,250 & 0 \\
\hline SUEPP-II/PREPP-II & 90,747 & 2,618 & 319 & 598,999 & 0 & 2,200 \\
\hline SIZE REDUCE & 112,215 & 0 & 80 & 0 & 0 & 0 \\
\hline TOTALS & 441,305 & 34,902 & 577 & $1,208,097$ & 86,250 & 2,200 \\
\hline
\end{tabular}

ASSOHPTIOMS: 1. 55\% of druned vaste and 808 of boxed waste is IRO (stored and nevly-gen)

2. 58 of nevly generated vaste vill be non-certifiable

3. Only non-certifiable IRU portion of nevly-generated raste vill go to INEL

4. If assay/RTR is not available all Stored Vaste will go to INEL

5. If assay/RTR is available Certifiable and LWW Stored Vaste

vill not go to INEL (based on percentages in (1)

6. Assay capibility will be available for the 'size reduce' boxes and waste nill be reduced to fit in ATax (i.e. only 808 shipped)

UASTE TO BE SEMT TO INEL FOR PROCESSING IN SUEPP/PREPP (OR SUEPP-II/PREPP-II)

> VITHOUT ASSAY CAPACITY FOR STORED HASTE

$$
\begin{array}{rr}
\text { TOTAL VOLUAE } & 459,572 \\
\text { TOTAL CONTAINERS } & 35,305
\end{array}
$$

\begin{tabular}{|c|c|c|c|c|c|c|}
\hline & & VOLUAE & - CONT. & & VOLUGE & conr. \\
\hline Snippa & STORED & 238,343 & 32,462 & Ship in STORED & 180,519 & 383 \\
\hline in TRUPA & MEULY GEN & 16,750 & 2,372 & ATAXOOLlY + HEVLY GEN & * 23,960 & 38 \\
\hline & TOTAL & 255,093 & 34,834 & TOTAL & 204,479 & 471 \\
\hline
\end{tabular}

> UITH ASSAY CAPACITY FOR STORED UASTE

TOTAL VOLURE 350,424

\begin{tabular}{|c|c|c|c|c|c|c|}
\hline & & VOLUHE & Cont. & & VOLUAE & COHT. \\
\hline Ship & STORED & 147,345 & 17,899 & Ship in STORED & 162,370 & 319 \\
\hline$n \pi$ & GEN & 16,750 & 2,372 & ATMXonly+ANEULY GEN & 23,960 & 88 \\
\hline & 50 & 164,095 & 20,270 & TOTAL & 186,330 & 407 \\
\hline
\end{tabular}

$$
\text { TOTAL COMTAIRERS } 20,678
$$

* SUEPP/PREPP sire raste

* SUEPP-II/PREPP-II size vaste plus IRU portion of size reduce vaste

SOURCE: provided by DOE-RL as part of Yorking Group 
TABLE B-2: SAVANNAH RIVER PLANT TRU WASTE INVENTORIES

\begin{tabular}{|c|c|c|c|c|c|c|}
\hline \multirow[b]{2}{*}{ CLASSIFICATIOH } & \multicolumn{3}{|c|}{ STORED } & \multicolumn{3}{|c|}{ GEVLY GEAERATED } \\
\hline & VOLUKE & DRUAS & BOXES & VOLUHE & DRUAS & BOXES \\
\hline CERTIFIABLE & 173,456 & 16,266 & 474 & 325,061 & 34,680 & 611 \\
\hline MOH-CERTIFIABLE & 35,371 & 3,115 & 110 & 36,108 & 3,850 & 00 \\
\hline LOH-LEVEL VASTE & 67,613 & 5,293 & 254 & 154,710 & 18,712 & 145 \\
\hline BOLX & 22,396 & 0 & 200 & 0 & 0 & U \\
\hline TOTALS & 298,836 & 24,674 & 1,038 & 515,879 & 57,242 & 824 \\
\hline
\end{tabular}

ASSUKPTIOHS: 1. All Menly-Generated boxes rill fit in IRUPACT

2. 508 of stored boxes (by volune and nunber) will fit in TROPACT

3. Only Mon-certifiable and Bulk nevly generated waste will go to INEL

4. All stored bulk raste is non-certifiable IRU (conservative)

5. If assay/RTR is not available all Stored Vaste will go to INEL

6. If assay/RTR is available Certifiable and LLV Stored Maste vill not go to IMEL

7. Average box volune $=112$ cubic feet, drun volune $=7.4$ cubic feet

UASTE TO BE SEIT TO INEL FOR PROCESSING IN SUEPP/PREPP (OR SUEPP-II/PREPP-II)

> VITHOUT ASSAY CAPACITY FOR STORED WASTE

$$
\begin{array}{rr}
\text { IOTAL VOLURE } & 334,948 \\
\text { TOTAL CONTAINERS } & 29,630
\end{array}
$$

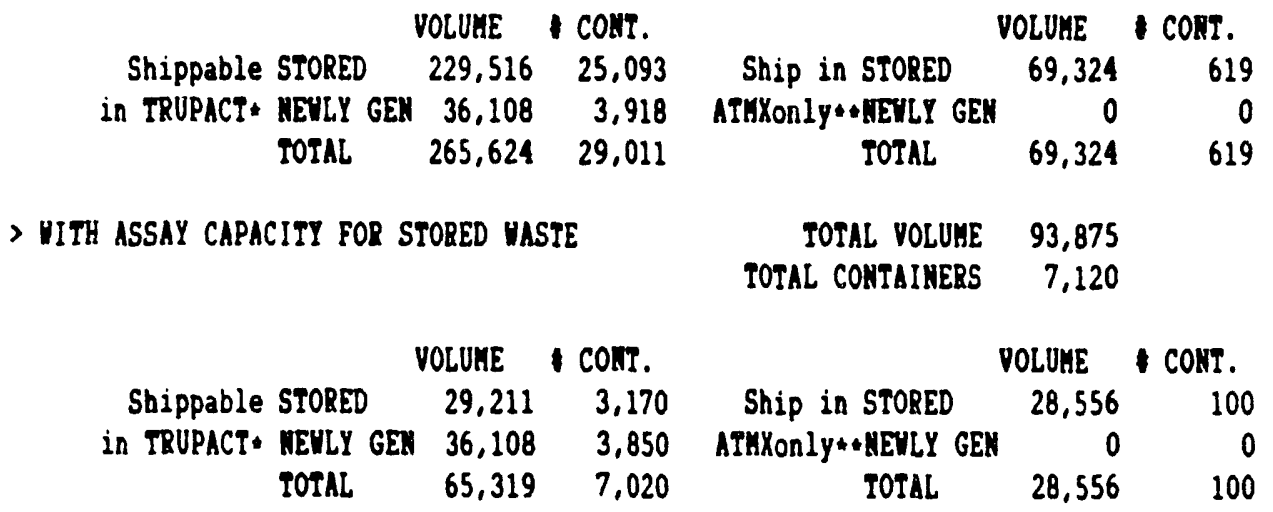

- All druas plus $50 x$ of boxes

- 508 of boxes plus all bulk

SOURCE: 'Transuranic Vaste Facility Cost Benefit Analysis - Draft', provided by DOE-SR as part of Vorking Group. 
TABLE B-3: COMBINED TRU WASTE INVENTORIES

> VITHOUT ASSAY CAPACITY. FOR STORED UASTE

\begin{tabular}{|c|c|c|c|c|c|}
\hline \multirow{3}{*}{$\begin{array}{r}\text { UASTE } \\
\text { HARDLIRG } \\
\text { CATAGORY }\end{array}$} & \multirow[b]{3}{*}{ SITE } & \multicolumn{2}{|c|}{ STORED } & \multicolumn{2}{|c|}{ MENLY GENERATED } \\
\hline & & VOLOHE & DUMBER & VOLUKE & DUMBER \\
\hline & & (CU FI) & CONTAIKER & $(\mathrm{CO} \mathrm{FT})$ & CONTAIRERS \\
\hline \multirow[t]{2}{*}{ SHEPP/PREPP } & HAMFORD & 238,343 & 32,462 & 16,750 & 2,372 \\
\hline & SRP & 229,516 & 25,093 & 36,108 & 3,918 \\
\hline \multirow[t]{2}{*}{ SUEPP-II/PREPP-II } & HAHFORD & 90,747 & 383 & 23,960 & 88 \\
\hline & SRP & 69,324 & 619 & 0 & 0 \\
\hline \multirow[t]{2}{*}{ SIZE REDUCE } & HANFORD & 89,772 & 80 & 0 & 0 \\
\hline & SRP & 0 & 0 & 0 & 0 \\
\hline & TOTAL & 717,702 & 58,637 & 76,818 & 6,378 \\
\hline
\end{tabular}

TOTAL VOLUAE 794,520 VOLUAE OF HAMFORD LLU TO BE BURIED AT INEL 109,148 TOTAL CONTAINERS 65,015 VOLUKE OF SRP LLV TO BE BURIED AT INEL 241,073

> WITH ASSAY CAPACITY FOR STORED YASTE

\begin{tabular}{|c|c|c|c|c|c|}
\hline UASTE & & & CORED & REULY & GERERATED \\
\hline HANDLING & & VOLUAE & RUABER & POLUAE & NUMBEER \\
\hline CATAGORY & SITE & (CU ET) & CONTAINER & (CU FT) & CONTAIHERS \\
\hline SHEPP/PREPP & HAHFORD & 147,345 & 17,899 & 16,750 & 2,372 \\
\hline & SRP & 29,211 & 3,170 & 36,108 & 3,850 \\
\hline SHEPP-II/PREPP-II & HAKFORD & 72,598 & 255 & 23,960 & 88 \\
\hline & SRP & 28,556 & 100 & 0 & 0 \\
\hline SIZE REDUCE & HAKFORD & 89,772 & 64 & 0 & 0 \\
\hline & SRP & 0 & 0 & 0 & 0 \\
\hline & TOTAL & 367,481 & 21,488 & 76,818 & 6,310 \\
\hline TOTAL VOLUAE & 444,299 & & & & \\
\hline TAL CONTAIAERS & 27,798 & & & & \\
\hline
\end{tabular}

TABLE B-4: PERCENTAGE OF WASTE IN EACH HANDLING CATAGORY

\begin{tabular}{|c|c|c|c|c|c|c|c|c|}
\hline $\begin{array}{l}\text { UASTE } \\
\text { HAMDLING } \\
\text { CATAGORY }\end{array}$ & $\begin{array}{l}\text { VOLUME } \\
\text { (CU ET) }\end{array}$ & $\begin{array}{l}\text { MUHBER OF } \\
\text { COHTAIMERS }\end{array}$ & $\begin{array}{r}\text { VOLUAE } \\
(8)\end{array}$ & $\begin{array}{r}\text { CONTAINERS } \\
(y)\end{array}$ & $\begin{array}{l}\text { VOLUHE } \\
\text { (CU FT) }\end{array}$ & $\begin{array}{l}\text { NUGBER OF } \\
\text { COHTAINERS }\end{array}$ & $\begin{array}{r}\text { VOLUAE } \\
\text { (x) }\end{array}$ & $\begin{array}{l}\text { OHTA INERS } \\
\text { (x) }\end{array}$ \\
\hline SUEPP/PREPP & 520,717 & 63,845 & 65.5 & 98.2 & 229,414 & 27,290 & 51.6 & 98.2 \\
\hline SUEPP-II/PREPP-II & 184,031 & 1,090 & 23.2 & 1.7 & 125,114 & 443 & 28.2 & 1.6 \\
\hline SIZE REDUCE & 89,772 & 80 & 11.3 & 0.1 & 89,772 & 64 & 20.2 & 0.2 \\
\hline TOTAL & 794,520 & 65,015 & 100 & 100 & 444,299 & 27,798 & 100 & 100 \\
\hline
\end{tabular}


APPENDIX C: TRANSPORTATION COSTS

The primary algorithm for evaluating an effective cost for shipment is stated as:

$$
\begin{aligned}
\text { Total Cost }= & \text { Capitol Costs + Shipping Costs }+ \text { Load/Unioad Cost } \\
& + \text { Operations/Maintaince Costs }
\end{aligned}
$$

The number of trips was calculated based on waste packages without overpacking. Overpacking would significantly increase the number of required trips but the overall cost per cubic foot would not increase dramatically. 


\begin{tabular}{|c|c|c|c|c|}
\hline \multirow[t]{2}{*}{ TOTAL VOLUAES VITHO } & $\begin{array}{l}\text { OT ASSAY: } \\
\text { HANFORD } \\
\text { SRP }\end{array}$ & $\begin{array}{l}794,520 \mathrm{CU} F \mathrm{FT} \\
459,572 \mathrm{CU} \mathrm{FT} \\
334,948 \mathrm{CU} \mathrm{FT}\end{array}$ & \multirow{2}{*}{\multicolumn{2}{|c|}{ | - - - - HANFORD $-\cdots$}} \\
\hline & \multicolumn{2}{|c|}{ 1-DSP } & & \\
\hline ROUHD TRIP COSTS & $\begin{array}{r}\text { ATHX } \\
\$ 4,748\end{array}$ & $\begin{array}{r}\text { TRUPACT } \\
\$ 5,500\end{array}$ & $\begin{array}{r}\text { ATHX } \\
84,748\end{array}$ & $\begin{array}{r}\text { TRUPACT } \\
\$ 5,500\end{array}$ \\
\hline CONVERSION SAVIRGS & 0.2 & 0.2 & 0.4 & 0.4 \\
\hline ACTUAL RI COSTS & $\$ 3,800$ & $\$ 4,400$ & $\$ 2,870$ & 83,300 \\
\hline CU FT/TRIP & 646.94 & 352.84 & 646.94 & 352.84 \\
\hline OF IRIPS & 518 & 949 & 710 & 1,302 \\
\hline $\begin{array}{l}\text { SHIPPING COSTS } \\
\text { :=::::::=:: }:=:\end{array}$ & $\begin{array}{l}\$ 1,967,417 \\
:=:=:=:=:=:=\end{array}$ & 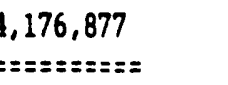 & $\begin{array}{l}82,038,786 \\
=:==:==:=\end{array}$ & $\begin{array}{l}1,298,232 \\
=:=:=:=:=\end{array}$ \\
\hline
\end{tabular}

\begin{tabular}{|c|c|c|c|c|}
\hline \multirow[t]{3}{*}{ TOTAL VOLU: } & $\begin{array}{l}\text { ASSAY: } \\
\text { HAMFORD } \\
\text { SRP }\end{array}$ & $\begin{array}{r}444,299 \mathrm{CV} F \mathrm{FT} \\
350,424 \mathrm{CU} F \mathrm{FT} \\
93,875 \mathrm{CU} F \mathrm{TT}\end{array}$ & & \\
\hline & \multicolumn{2}{|c|}{$1-1-1$} & \multicolumn{2}{|c|}{ 1 } \\
\hline & ATMX & IRUPACT & ATAX & IRUPACT \\
\hline BOUHD TRIP COSTS & 84,748 & 85,500 & 84,748 & $\$ 5,500$ \\
\hline CONVERSION SAVINGS & 0.2 & 0.2 & 0.4 & 0.4 \\
\hline ACTUAL RT COSTS & $\$ 3,800$ & $\$ 4,400$ & $\$ 2,870$ & 83,300 \\
\hline CU FT/TRIP & 646.94 & 352.84 & 646.94 & 352.84 \\
\hline OF IRIPS & 145 & 266 & 542 & 993 \\
\hline SHIPPING COSTS & $\$ 551,404$ & $1,170,644$ & $\$ 1,554,577$ & $, 277,408$ \\
\hline
\end{tabular}

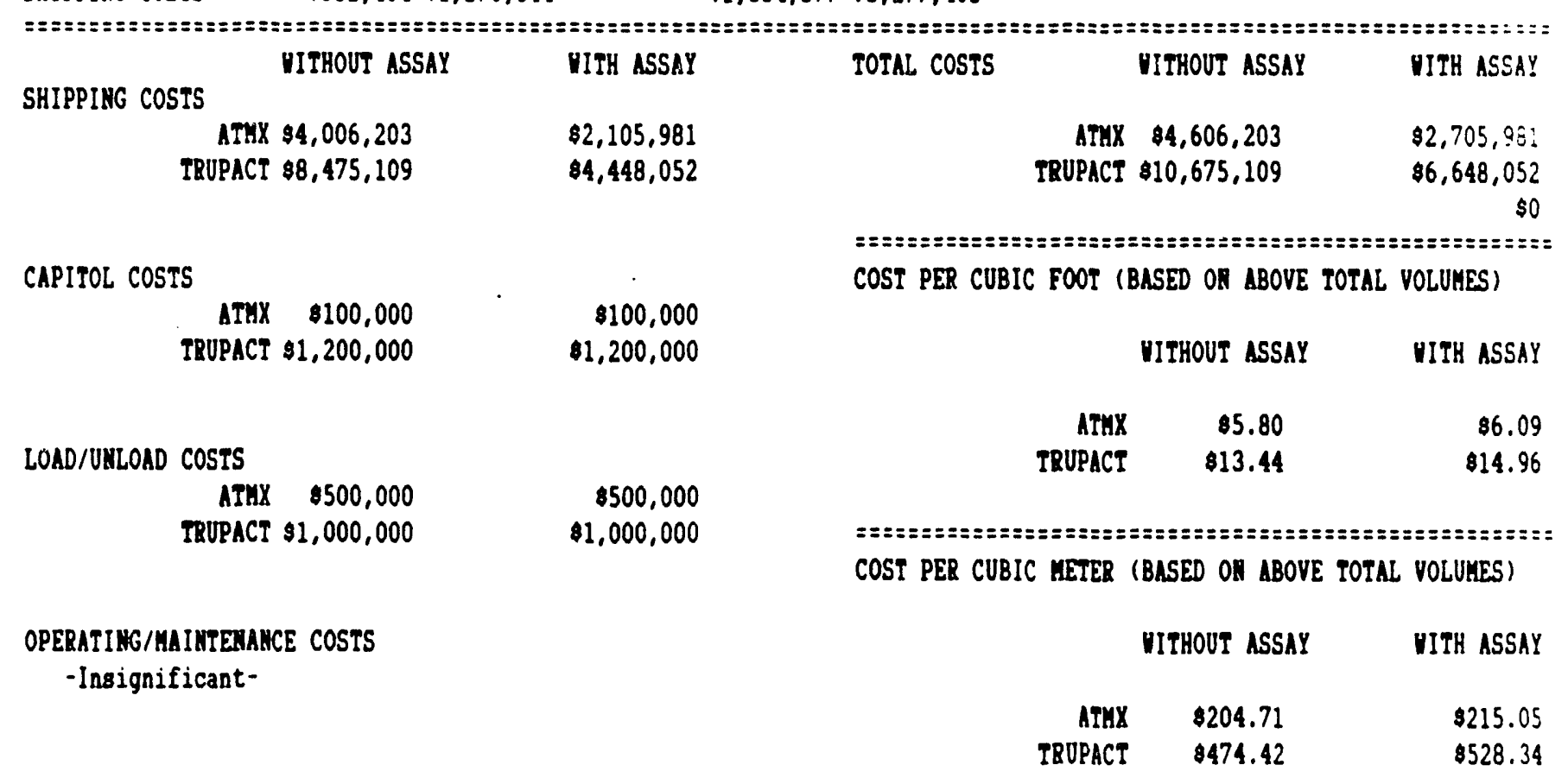


SAVANNAH RIVER PLANT FACILITIES:

1

$2^{\text {Scenario }_{3}} 4$

1) Retrieval Equipment

- Vacuum Truck

- Handling Canisters

-Transportation Cask

-Trailer

-Shielded Backhoe

$\begin{array}{llll}x & x & x & x \\ x & x & x & x \\ x & x & x & x \\ x & x & x & x \\ x & x & x & x\end{array}$

2) Facility

-Storage and Opening Cell

- Hardened Cell

-Vent \& Purge

-Drum Out

-Shipping Area

- Change Rooms

-Maint. Area

-Control Room Area

-HP Facilities

-Sand Filter

-Assay System

-RTR System

-Box Handling

- Telerobot

-Plasma Torch

-Work Table

-Process Cell Area

-Shredder

- Cementation

$\begin{array}{llll}x & x & x & x \\ x & x & x & x \\ x & x & x & x \\ x & x & x & x \\ x & x & x & x \\ x & x & x & x \\ x & x & x & x \\ x & x & x & x \\ x & x & x & x \\ x & x & x & x \\ x & \star & x & \star \\ x & \star & x & \star \\ x & & x & \\ x & & x & \\ x & & x & \\ x & & x & \\ x & & x & \\ x & & x & \\ x & & x & \end{array}$

3) Rail Car Loading Facilities $X$

$x \quad x \quad x$

* Assay and RTR Systems will only be provided on those sub-scenarios that include assay per the text of the document.

HANFORD FACILITIES:

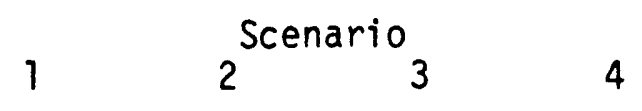

DESCRIPTIONS TO BE ADDED AT A LATER DATE! 
APPENDIX E: HANFORD AND SAVANNAH RIVER PLANT FACILITY COSTS

Facility construction costs and operating costs were provided by the respective sites. Shipping costs and total costs have been computed based on the numbers presented in Appendicies $B$ and $C$. 
HANFORD COSTS FOR SHIPPING UASTES TO INEL FOR PROCESSING (MILLIONS OF DOLLARS)

\begin{tabular}{|c|c|c|c|c|c|c|}
\hline $\begin{array}{l}\text { YASTE } \\
\text { HANDLING } \\
\text { CATAGORY }\end{array}$ & $\begin{array}{l}\text { VOLUHE } \\
\text { (CU FT) }\end{array}$ & $\begin{array}{l}\text { NUMBER OF } \\
\text { CONTAINERS }\end{array}$ & $\begin{array}{r}\text { HANFORD } \\
\text { FACILITY } \\
\text { COSTS }\end{array}$ & $\begin{array}{r}\text { HAMFORD } \\
\text { OPERATIRG } \\
\text { COSTS }\end{array}$ & $\begin{array}{r}\text { IRUPACT } \\
\text { SHIPPING } \\
\text { COSTS }\end{array}$ & $\begin{array}{r}\text { ATHX } \\
\text { SHIPPING } \\
\text { COSTS }\end{array}$ \\
\hline \multicolumn{7}{|l|}{ SUEPP/PREPP } \\
\hline PHOUT ASSI & 255,0 & & 95 & 820 & $\$ 3$ & 91 \\
\hline B) UITH ASSAY & 164,095 & 20,270 & $\$ 13$ & 876 & 82 & 81 \\
\hline
\end{tabular}

SUEPP-II/PREPP-II

$\begin{array}{lrrllll}\text { A) UITHOUT ASSAY } & 114,707 & 471 & * & * & * & \$ 1 \\ \text { B) UITH ASSAY } & 96,558 & 343 & * & * & * & \$ 1\end{array}$

SIZE REDUCE

$\begin{array}{lllllll}\text { A) UITHOUT ASSAY } & 89,772 & 80 & 830 & 820 & \# & \$ 1 \\ \text { B) UITH ASSAY } & 89,772 & 64 & 830 & 820 & \# & \$ 1\end{array}$

- Costs included in above nunbers

* Vaste is too large for IRUPACT

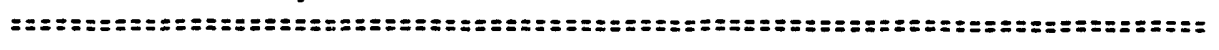
TOTALS

$\begin{array}{lllllll}\text { A) VITHOUT ASSAY } & 459,572 & 35,385 & \$ 35 & \$ 40 & 83 & \$ 3\end{array}$

B) VITH ASSAY $350,424 \quad 20,678 \quad 843 \quad 896 \quad 82 \quad 82$

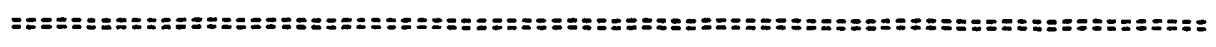

TOTAL COSTS = SITE FACILITY COSTES + SITE OPERATING COSTS + INEL COSTS +SHIPPIHG COSTS + INCREASE IN LLU BURIAL COSTS

ALL UASTE SHIPPED IR ATHX

A) VITHOUT ASSAY \$162 MILLION

B) UITH ASSAY 8223 ทILLIOH
UASTE SHIPPED IN COMBIMATION ATHX \& TRUPACT

A) UITHOUT ASSAY \$164 MILUION

B) UITH ASSAY $\$ 224$ GILLION 
Assunption: Greater Confinesent Disposal (GCD) is an acceptable alternative disposal method for Hanford raste packaged in boxes too large for shipment in the Arux.

\begin{tabular}{|c|c|c|c|}
\hline & & MITHOUT ASSAY & UITH ASSAY \\
\hline \multirow[t]{4}{*}{ Costs Reduced: } & Facility Costs & $\$ 30$ & 830 \\
\hline & Operating Costs & 820 & 820 \\
\hline & Shipping Costs & $\$ 1$ & $\$ 1$ \\
\hline & LWV Burial Costs & 80 & 80 \\
\hline \multirow{2}{*}{ Costs Increased: } & GCD Costs & $\$ 16$ & $\$ 16$ \\
\hline & 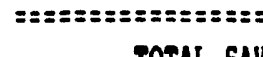 & 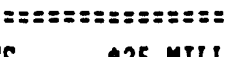 & $=:=:=$ \\
\hline
\end{tabular}

TOTAL COSTS FOR SHIPPIMG ONLY HAMFORD UASTE TO INEL ALL SHIPPED II ATMX A) UITHOUT ASSAY 8128 MILLION SHIPPED II COHB. ATHX \& IBUPACT B) UITH ASSAY 8188 MILLIOH

A) WITHOUT ASSAY

$\$ 130$ MILLIOH

B) YITH ASSAY

$\$ 190$ MILLION

TOTAL COSTS FOR SHIPPIMG ALL UASTE TO INEL

ALL SHIPPED IN ATHX

A) WITHOUT ASSAY

B) VITH ASSAY
8409 MILLION

$\$ 466$ MILLION
SHIPPED IN COHB. ATHX \& IRUPACT

A) UITHOUT ASSAY $\$ 413$ HILLIOH

B) VITH ASSAY
8468 MILLION 
TABLE E-3: SAVANNAH RIVER PLANT COSTS FOR SHIPPING WASTE TO INEL FOR PROCESSING

SRP COSTS FOR SHIPPIMG UASTES IO INEL FOR PROCESSING (MILLIONS OF DOLLARS)

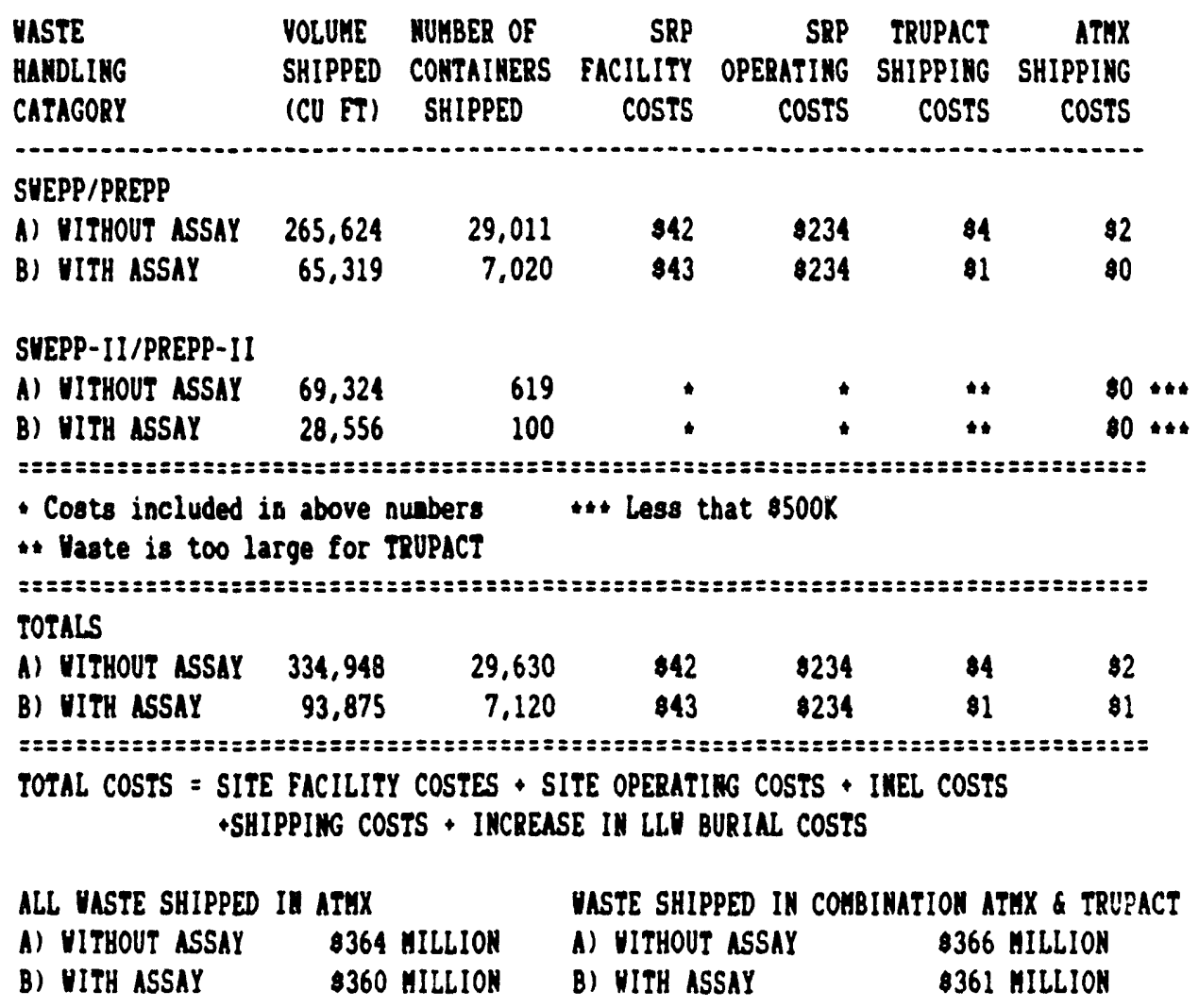


TOTAL COSTS FOR SHIPPIMG UASTES TO IMEL FOR PROCESSING (MILLIOHS OF DOLLARS)

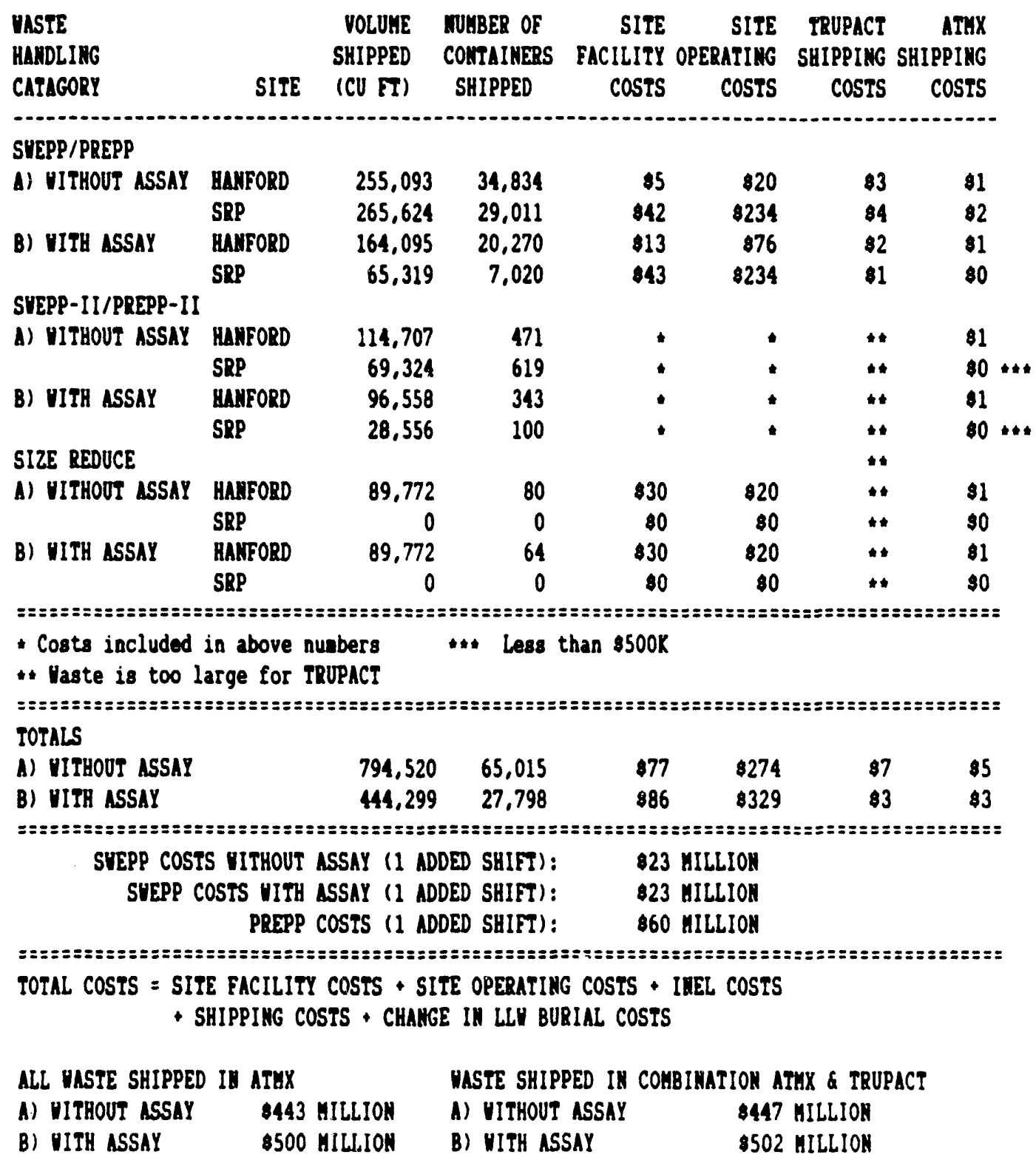


APPENDIX F : INDEPENDANT REVIEW COMMITTEE COMMENTS TO FINAL DRAFT Attached is the comments of the Defense Waste Management Programs Independant Review Committee (IRC) to the May 1986 draft of this document. These comments have not been incorporated. 


\title{
S.E. Logan and Associates, Inc.
}

\author{
1054 Buckman Road \\ Santa Fe, New Mexico 87501 \\ (505) $988-2407$ \\ for UPS, add: La Tierra 89
}

September 29,1986

Mr. Kirk B. MoKinley

Joint Integration Office

P.O. Box 1350

Albuquerque, NM 87190-3150

Re: IRC Meeting in Washington, D.C., August 12, 1986

Dear Kirk:

The IRC met in Washington, D.C. on Aligust $12,1986$.

\section{ATTENDEES}

Five Members of the IRC attended: William Brobst, Howara Kreider, Stanley Logan, Roy Post, and Robert Ramsey. Bruce Wilson is on sabbatical leave in Scotland, and one position on the committee is vacant. Others attending were John Mathur, DOE/HQ, Dana Beaulieu, JIO/DOE, Lee Morton, JIO/RI, and Drew Detamore, JIO/RI.

\section{MEETING SUMMARY}

This was the first meeting of the IRC on the subject of proposed centralized processing of $\mathrm{CH}$ TRU waste. The preliminary draft report by the JIO was discussed and suggestions for correcting and clarifying the report were assembled.

\section{DISCUSSION TOPIC}

The purpose of this IRC meeting was a preliminary discussion of centralized processing of $\mathrm{CH}$ TRU waste. Prior to tha meeting, IRC members reviewed the preliminary draft of DOE-JIO-011, "Centralized Processing of Contact-Handled TRU Waste Feasibility Analysis." This report considered four major scenarios with breakdown into a total of eleven options. The base case scenario is processing at all three sites: INEL, Hanford, and SRP. Also reviewed as background information was DOE-JIO-004, "TRU Waste Management Program Cost/Schedule Optimization Analysis."

The IRC recognizes the preliminary nature of the draft centralized processing report and appreciates the opportunity to review it and provide input at this early stage. We understand that a revised version is in process. During IRC discussion vith the other attendees, additional clarification on intent of the 
study and on contents of the draft report were obtained. As part of this discussion, IRC members provided a number of suggestions for correction and clarification to aid in the immediate revision efforts. In the following paragraphs, items developed during the initial discussion, plus items developed during the IRC caucus are presented. Some elaboration of these items was developed by IRC members subsequent to the August meeting and is included here.

The TRU processing facilities at Idaho have excess capacity as a consequence of relaxation of certain requirements on the handing of TRU contaminated waste from the defense programs. This relaxation to 100 nanocuries per gram as the basis for WIPP disposal means that much material is committed to land burial as LLW that would otherwise have been destined for shipment to and emplacement in the WIPP.

\section{Objectives of Centralized Processing Strategy}

The basic premise of the study is to investigate centralized processing as a means to optimize the cost and schedule of the TRU Waste Management Program. The analysis, however, seems to have as its primary objective the avoidance of capital cost for waste treatment facilities. It is notable that the cost differential estimates are in the range of only 10 to $20 \%$ of the program for near autonomous processing of waste (base case). Hence, even small set backs in the centralized option could wipe out all economic advantage.

Cost Allocation Assumptions

Some of the assumptions have a large impact on the comparative costs of the various scenario options. For example, the INEL processing costs are assumed to be the same for all centralized processing options, whether Hanford, SRP, or both are processed, and whether with or without assay, even though the volumes to be processed vary by a. factor of up to 8.5 (as for option 2 a compared to $4 \mathrm{~b}$ ). If INEL processing costs are reapportioned in proportion to volumes handled, the $\$ 4 \mathrm{M}$ loss for option $2 \mathrm{~b}$ becomes a \$33M gain. Similarly, the range of cost differences for all options tends to narrow and the order changes as more realistic cost apportioning is applied.

Processing of Pu-238 Waste

The question of just how well Pu-238 waste can be handled and treated at INEL is still an open question, and must be resolved before a decision can be made on processing that waste at PREPP. SR's Pu-238 waste had a high Americium content, and just how that would be provided for at PREPP was not discussed in DOE-JIO-011, other than the conclusion that it would be no problem. The justification for the rationale leading to that conclusion needs to be included, in detail, in the report. 
The benefit of handling Pu-238 in separate and specifically designed facilities at SRP, because of its pivotal role in production and handling of this material should be considered as an alternative. The complication of handling the higher specific activity of the contamination, combined with the nature of the waste inventory at SRP described as having a high fraction of combustibles, indicates that untreated shipment will entail a higher risk.

Thus, another processing scenario option became apparent during the IRC's discussions: process all Pu-238 waste at Savannah River, and other TRU waste from Hanford and other sites at INEL. SRP inay also be able to process some or all of its Pu-239 waste along with Pu-238 waste. This would provide a backup in case of operating or design problems at PREPP. Technically, this makes more sense as well, since PREPP would then be free of the highactivity Pu-238 waste; operations at PREPP would be much simpler and less costly in that option. Also, it would save some transport deadheading, although the cost savings there would be small. Politically, it might be the only acceptable option for handling the $\mathrm{Pu}-238$ waste.

Backup Processing Capability

If centralized processing is adopted, there is a possibility of not having any or at best inadequate processing capability within the Defense Waste complex should the PREPP suffer an operational upset. All the processing eggs are in one basket.

\section{Transportation Costs}

DOE-JIO-011 ignores the extra cost of transportation due to the impending redesign of TRUPACT-II-A. That redesign is likely to produce a 50\% increase in TRUPACT manufacturing cost, a $20 \%$ decrease in payioad resulting in a $25 \%$ increase in the number of shipments required, and probably a total increase of about $30 \%$ in the system transportation cost.

Further, the entire scenario costs for transport seem far too low. Only a portion of the costs seem to have been presented here. Total costs include fabrication and maintenance of TRUPACTs, freight charges, handing and packaging labor and materials, vehicle purchase and maintenance, and administrative overhead. The costs of the extra (spare) TRUPACTs seem to be missing, as well. Listed costs appear to represent only one TRUPACT and one ATMX car. Where are the costs for the same factors as above for ATMX cars (an increaing liklinood)? If more ATMX cars are needed, they will have to be redesigned, since no new cars may be made under those original and now obsolete specifications.

DOE-JIO-011 gives only the extremes in considering the mix of rail and highway shipments. What mix is most likely, particularly in view of the apparent decision to go to a major 
redesign of the TRUPACT for double containment? Table $\mathrm{C}-1$ needs to be revised to show some mix ratios, with credible cost figures. Load and unload costs are listed in Table C-1 as being the same whether with or without assay; there is almost a factor of two difference in the volume handled.

\section{Transportation Packaging}

WIPP-WAC certification is not a prerequesite to transport of TRU waste to a centralized processing site. Further, the "requirement" that inside drums and boxes meet Type A requirements is a WIPP acceptance criteria, not a DOT or NRC transport criteria. For example, for shipment from MOUND to INEL for processing, the boxes do not need to meet Type A requirements. For shipment from Mound to WIPP for disposal, they do.

The use of the term "container" is inconsistent and confusing. Is the container the TRUPACT itself, the TRUPACT inner liner (if added), or the 55 gallon drum? The terms "container," "packaging," "package," "receptacle," "drum," and "box," should be defined and used consistently. The DOT regulations should be used in making those definitions.

Institutional Issues

The necessity for an expanded shipment program for unprocessed and hence unpassivated and non-volume reduced or non-immobilized waste materials is accompanied by a consequent increased potential for accident and exposure to the handing workers and to the public.

There needs to be a management analysis of both cost-benefit to the autonomous program and cost-risk of the centralized processing case.

Additional IRC Concerns

The IRC has concerns about the accuracy of the estimates used as the basis of the assessment cases in this study. The data presented is in many cases insufficient or inconsistert. Assumptions are not fully supported. The IRC is concerned that the evaluation of the greater issue: a comprehensive and timely program of TRU waste management, integrating generating facilities and disposal facilities, not be compromised by the appeal of near term cost avoidance. The real cost of any lost opportunity to provide needed flexibility and capability must be a factor in the consideration of centralized processing.

There is a need for uniform ground rules for management. What are the minimum requirements for transport to centralized processing? Is there material that would need some processing before shipment and would some processing then justify full processing facilities? How does the proposed plan relate to plans at SRP to incorporate Pu-238 waste in HLW? 
The IRC report on the review of double containment and continuous venting issues (April 4, 1986) recommended (page 8): "Increase processing for passivation, immobilization, and volume reduction of combustible waste. Specifically, drums of soft waste in excess of $20 \mathrm{Ci}$ should be considered for processing until processing capacity is fully utilized." This recommendation is also expected to achieve cost reduction. If centralized processing substantially fills the INEL processing capacity, would this then preclude implementing the IRC recommendation? Are cost savings from centralized processing partially of set by lost opportunity for cost reduction through additional processing of INEL TRU wastes?

Because of the relaxation to 100 nanocuries per gram in the definition of TRU, there is the prospect that untreated material having up to 100 nanocuries per gram contamination will now be committed to trench burial in Idaho, where such burial has caused environmental problems in the past. This would be exacerbated by options $2 a, 2 c, 3 a$, and $3 c$ (shipment to INEL without assay) which would introduce up to more than 350,000 cubic feet of additional LLW for burial at INEL. This potential increase of LLW is recognized as an issue in DOE-JIO-011. Subsequent to the August 12 IRC meeting, an opinion has been expressed within the IRC that any excess capacity that is available at INEL should also be considered as processing capacity to improve the disposal condition of TRU wastes that are less than the 100 nanocuries per gram but, nevertheless, could constitute an environmental problem if land buried in an untreated situation. Allocation of processing capacity to LLW affects availability for centralized processing and the bases for cost estimates.

Again, the IRC emphasizes that we recognize the preliminary status of the centralized processing study. The IRC believes that the early draft version of the report does not support a decision either way (pro or con) with respect to centralized processing. The IRC does believe that a decision is warranted, and that the matter should not be left to default.

\section{IRC RECOMMENDATIONS}

i. The IRC recommends that the DOE not make a decision on centralized processing based on DOE-JIO-011 in its present form.

2. Redo DOE-JIO-011 with better data and fully supported assumptions.

3. Resolve questions surrounding processing of Pu-238 waste at INEL.

4. Examine an additional option to scenarios 2 and 4 : process all Pu-238 waste at the SRP and other TRU waste at INEL.

5. Determine whether utilization of INEL processing capacity for 
centralized processing precludes additional processing of INEL wastes.

6. Determine needs for INEL processing capacity to improve the disposal condition of LLW.

\section{FUTURE MEETINGS}

A revised draft of DOE-JIO-011 is expected to to be available by early December. Prior to that time, revised portions may be made available to the IRC for review. The IRC will meet in conjunction with the TRU Waste Update Meeting 13 in December. If necessary, an additional IRC meeting will be held prior to the update meeting.

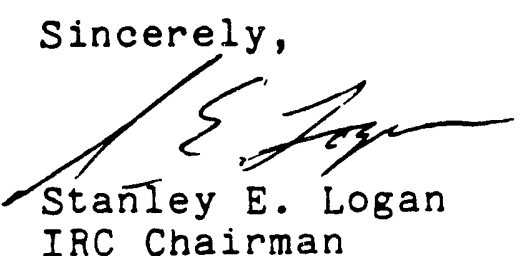

cc: W.A. Brobst, IRC

J.D. Detamore, JIO/RI

H.B. Kreider, Jr., IRC

M.H. McFadden, JIO/DOE

R.L. Morton, JIO/RI

T.H. Nielsen, JIO/RI

R.G. Post, IRC

R.W. Ramsey, IRC

D.B. Wilson, IRC 
APPENDIX G: DOE SAVANNAH RIVER COMMENTS TO FINAL DRAFT

Attached is the comments of the DOE Savannah River DWG member to the May 1986 draft of this document. These comments have not been incorporated. 


\author{
Department of Energy \\ Savannah River Operations Office \\ P.O. Box A \\ Aiken, South Carolina 29802
}

\title{
AUG 191086
}

J. M. McGough, Jr., Director

Waste Management and Transportation

Development Division, AL

DEPARTMENT OF ENERGY (DOE) WORKING GROUP, CENTRALIZED PROCESSING, DRAFT FINAL REPORT (REFERENCE THE MEMORANDUM, BEAULIEU/ADDRESSEES, DATED JULY 9, 1986)

The Savannah River Operations Office (SR) has some concerns with the subject document. Additional information, as required, on the major concerns will be addressed in a memorandum from SR to Albuquerque (AL). However, for the purposes of the meeting between our staffs on August 13, 1986, at DOE-Germantown, here are the main issues of concern to SR. Details of these concerns and full report comments will be provided during this meeting.

The "without assay" scenario is not a viable option. The Savannah River Plant (SRP) cannot ship unassayed waste to Idaho National Engineering Laboratory (INEL) due to the criticality and safety concerns which may result because the container contents may not be accurately known.

$\circ$

Some SRP waste will require size reduction prior to shipping to INEL in the Transuranic (TRU) Package Transporter (TRUPACT). The costs for this size reduction are not included in this scenario.

$\circ$

The cost analysis must include total shipping cost. For SRP waste, the cost to ship waste from SRP to INEL to Waste Isolation Pilot Plant

(WIPP) must be compared to the cost to ship SRP to WIPP.

in the cost summary table. Rather, the additional cost would be for

\$8 $M$ for assay at Hanford seems high.

$\circ$

Cost tables must specify year of dollars and escalation rates used.

0 In cases 3 and 4 , one site should not be charged the entire \$83 MM INEL
operating cost.

- Process Engineering Pilot Plant (PREPP) Waste Evaluation

- SRP drums weigh 75-100 pounds

- Decay daughter products must be considered in dose rate calculation

SRP TRU Waste Inventories table needs further explanation of how the volume numbers were calculated and what years are covered. 
In addition, the following major institutional issues are identified as you requested:

- States between South Carolina and Idaho would now also be impacted by the TRU program, where previously only the states between South Carolina and New Mexico were affected. Including these additional states could be significant given the attention recent DOE transportation activities have drawn.

- The protection (and the perception of protection) of worker and citizen health and safety must be provided. The TRU Program has taken a lot of credit with the state of New Mexico for the certification of waste prior to its transportation to and emplacement in WIPP, thereby assuring the politicians and citizens of New Mexico that WIPP poses no hazard to the environment or people of the state. It is doubtful that this perception of protection could be provided to the workers and the citizens of the states exposed to the handling and transportation of the non-x-rayed and non-assayed waste, since we have used the certification of TRU waste to convey the perception of safety in the past.

In conclusion, the non-x-ray/non-assay scenarios are not viable for technical and institutional reasons. In addition, centralized processing does not provide any cost savings if the waste is $x$-rayed and assayed prior to transporting for centralized processing. Therefore, we recommend that the report conclusion be that for technical and institutional reasons, centralized processing does not provide any cost savings to the national TRU Program.

If your staff would like any additional information prior to the meeting, they may contact Julie D'Ambrosia of my staff on FTS 239-5542.

OWM: JTD:epm

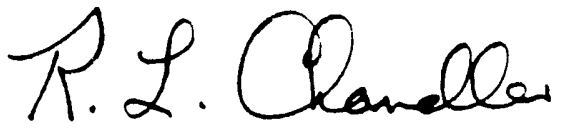

R. L. Chandler, Acting Director Process and Weapons Division

$c c:$ S. P. Mathur (DP-123), HQ 
APPENDIX H: DOE HANFORD COMMENTS TO FINAL DRAFT

Attached is the comments of the DOE Hanford DWG member to the May 1986

draft of this document. These comments have not been incorporated. 


\title{
Departn.ont of Energy
}

Richland Operations Office

P.O. Box 550

Richland, Washington 99352

\section{NUG 131986}

\author{
J. M. McGough \\ Waste Management Transportation \\ Development Division, AL
}

DOE WORKING GROUP, CENTRALIZED PROCESSING, DRAFT FINAL REPORT

We have completed review of the subject draft report and based on the enclosed Findings we recommend the following:

1. That the data contained in the draft document be presented to DOE-HQ in an informational briefing.

2. That the document be kept in draft and not issued.

3. That no further work be expended on Centralized Processing but that further consideration should be given to site specific options which could result in cost reduction and/or more effective use of limited funding.

If publication of a final document is deemed necessary we strongly suggest that the scenarios dealing with GCD of Hanford stored TRU waste (oversize boxes) be highly qualified. Also, we believe the scenarios dealing with the shipment of unassayed waste should be deleted as not viable options.

If you have any questions please contact $N$. T. Karagianes of my staff on FTS 444-6606.

WMD : NTK

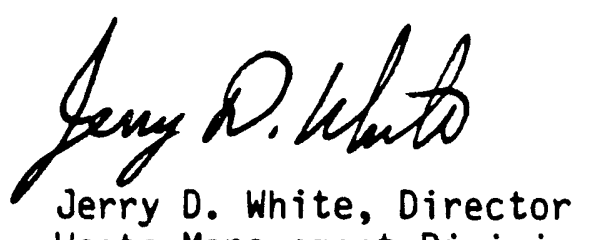

Enclosure

cc w/encl:

S. P. Mathur, HQ/DP-123

M. H. McF adden, DOE/AL

D. H. Beaulieu, DOE/AL

J. D. Ambrosia, DOE/SR

K. Hunter, DOE/ID 


\section{Centralized Processing \\ Draft Final Report \\ Hanford Findings}

1. In the Introduction delete the last sentence on the first page which reads, "Although the costs are strictly a "rough order of magnitude" the results of this assessment now provides DOE-HQ with sufficient information with which it can make a determination of the most cost efficient program for the processing of $\mathrm{CH}-\mathrm{TRU}$ wastes." First, this is a conclusion not an introduction-type statement and second, it does not agree with Hanford's findings and recommendations.

2. The validity of projected "cost savings" is highly questionable since comparisons are made between reasonably well defined costs (Engineering Studies) in the base case with ROM costs in the options. Hanford costs for example, have an accuracy of $+50 \%$ to $+75 \%$. If Hanford costs, which represent only about $25 \%$ of the total costs, were exceeded by only $40 \%$ the suggested "cost saving" of \$5l million dollars in Option 2(a) would be negated. Further, although the ROM cost estimates are alluded to in the General Issues section, the implication is that all costs could rise equally thereby maintaining the "cost savings difference." This would be extremely unlikely since the more accurate base case dollars would certainly rise by a lower percentage than the ROM figures, thereby reducing or eliminating cost differences ("savings").

3. The document lists a large number of highly sensitive institutional and technical issues not the least of which is the use of GCD for Hanford stored TRU waste (oversize boxes). Currently based on early comments on the HDW-EIS, Hanford sees a regional consensus to move forward with the disposal of three types of waste; one being the shipment of stored TRU waste to WIPP. Final decisions will be made at a later date but it is key to recognize that these decisions should be made on environmentally sound basis rather than on a cost basis alone. From this standpoint the publication of a DOE document at this time alluding to cost savings and suggesting changes in program direction for this reason could do serious harm to DOE credibility.

4. The issue of transportation safety has barely been addressed from the standpoint of moving unassayed materials. Many of Hanford's earlier (early to mid-1970's) measurements and records on stored TRU Wastes are at best minimal. Further, the inventory of potentially mixed wastes complicates the issue even more. The assumption in the report that overpacking would satisfy transportation safety issues is highly simplistic particularly when considering the States' interest in nuclear transport activities and our inability to guarantee waste drum contents. 
APPENDIX I: DOE IDAHO COMMENTS TO FINAL DRAFT

Attached is the comments of the DOE Idaho DWG member to the May 1986

draft of this document. These comments have not been incorporated. 
DATE: August 28, 1986

SUBJECT:

DOE Working Group Report "Centralized Processing (July 1986),"

Review Comments On

TO:

Dana Beaulieu

DOE-AL

DOE-ID does not believe that the subject report is substantive in that

findings or recommendations based on the data within the report are lacking or minimal. In addition, we question the objectivity of costs provided by SRP and Hanford, and the accuracy of costs detailed for the INEL. SRP and Hanford costs appear excessive and are not supported. The estimate of $\$ 83 M$ to process both SRP and Hanford waste at the INEL is excessive. The INEL estimate for this option is $\$ 46.1 \mathrm{M}$.

Selection of a strategy for SRP and Hanford wastes will result in significant cost impacts (teins of millions of dollars) to the DOE system. This report does not provide the necessary basis for the rational development of such a strategy. Because of the potential cost savings, we strongly recommend that an independent group be funded and provided with necessary resources and support to complete a thorough, unbiased alternatives evaluation. Detailed comments are attached.

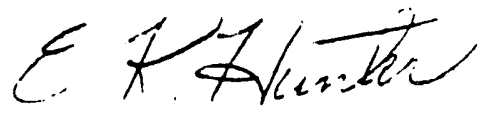

E. Kent Hunter Waste Management Branch

Attachment

CC: D. L. Uhl, EG\&G, w/att.

T. B. Hindman, DOE-HQ, w/att. 
INEL COMMENTS ON DOE WORKING GROUP

CENTRALIZED PROCESSING REPORT (JUTY 1986)

\begin{tabular}{|c|c|c|c|c|}
\hline Item & Page & Section & Paragraph & Comment \\
\hline 1 & 2 & $\begin{array}{l}\text { Second, } \\
\text { Cover Page }\end{array}$ & -- & $\begin{array}{l}\text { K. E. Hunter should be } \\
\text { E. K. Hunter }\end{array}$ \\
\hline 2 & 5 & Introduction & 1 & $\begin{array}{l}\text { The words "contact-handled" should } \\
\text { be added to describe the type of } \\
\text { TRU waste that would be processed. }\end{array}$ \\
\hline 3 & " & " & 2 & $\begin{array}{l}\text { It would seem that "rough order } \\
\text { of magnitude" costs for a report } \\
\text { that impacts the DOE system in } \\
\text { terms of tens of millions of } \\
\text { dollars reflects the need to } \\
\text { have an unbiased alternatives } \\
\text { evaluation conducted by an } \\
\text { independent group that has the } \\
\text { time and resources to put such } \\
\text { a report together. }\end{array}$ \\
\hline 4 & 6 & Approach & 1 & $\begin{array}{l}\text { The statement concerning evaluating } \\
\text { the INEL facilities for suitability } \\
\text { with Hanford and SRP wastes is not } \\
\text { totally accurate. There are not } \\
\text { large "general differences" in } \\
\text { the waste. The PREPP evaluations } \\
\text { for SRP and Hanford conclude the } \\
\text { wastes are similar to Rocky Flats } \\
\text { (i.e. INEL) wastes. }\end{array}$ \\
\hline 5 & 8 & $\begin{array}{l}\text { Discussion of } \\
\text { Scenarios }\end{array}$ & Scenario & $\begin{array}{l}\text { Hanford, even with their own } \\
\text { facilities, may have some TRU } \\
\text { waste not acceptable at WIPP } \\
\text { and would require GCD. }\end{array}$ \\
\hline 6 & $"$ & $"$ & $"$ & $\begin{array}{l}\text { Last sentence - change "s'iorage" } \\
\text { to "disposal" for wastes shipped } \\
\text { to WIPP. }\end{array}$ \\
\hline 7 & " & " & Option A & $\begin{array}{l}\text { The assumption that a shipping } \\
\text { container is available for wastes } \\
\text { that contain free liquids, parti- } \\
\text { culates, etc. should be stated. }\end{array}$ \\
\hline
\end{tabular}




$\begin{array}{lccc}\begin{array}{l}\text { Item } \\ 8\end{array} & 9 & \begin{array}{l}\text { Page } \\ \text { Option } 6\end{array} & \frac{\text { Paragraph }}{1} \\ 9 & 9 & . & 2 \\ 10 & 10 & \begin{array}{l}\text { Transportation } \\ \text { Option }\end{array} \\ 11 & 12 & \text { " } & \text { TRUPACT (1) } \\ 12 & 12 & \text { ATMX } \\ 13 & 14 & \text { Summary of Costs }\end{array}$

Comment

A statement concerning what will happen to LLW should be added, or clarified by inserting "TRU", where applicable, for wastes sent to INEL for processing.

Assaying does not necessarily "significantly" increase the costs at each site. No consideration has been given to use of the mobile systems currently under construction or other less expensive alternatives.

The table shows four shipping containers, not three. Should TRUPACT II be listed since it doesn't exist?

The SARP interpretation does not impact certifying waste to the WIPP-WAC. It does impact transportation to WIPP.

Last sentence - "meat" should be "meet".

In general, the INEL questions the objectivity of the numbers presented for the various options. Specifically: (1) Option 2 a) and b) - Why does Hanford need $\$ 8 M$ for assay and SRP only \$IM? Assay systems are not that expensive.

(2) Option 2 c) and d) - One of these should say "assay", the other "no assay".

(3) The site operating costs for Hanford under Option 2 b) and c) indicate it will cost $\$ 56 \mathrm{M}$ to assay the waste. This is extremely high $\left(\$ 116 / \mathrm{ft}^{3}\right)$. By your figures, INEL could 


$\frac{\text { Item }}{13} \frac{\text { Page }}{14} \frac{\text { Section }}{\text { Summarv of Costs (Cont.) }}$

$14 \quad 15 \quad$ Scenario $2 \quad$ Option a, c, \& d

$15 \quad 16 \quad$ Scenario $3 \quad$ Option a

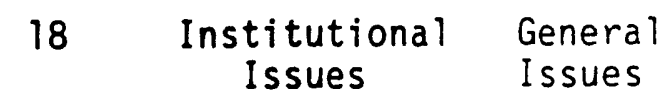

\section{Comment}

process the Hanford waste for less (\$41M) than Hanford can just assay the waste. Yet, SRP says it costs nothing to assay their waste. This discrepancy should be resolved.

(4) Option 3 and 4 - It is not clear why it would cost $\$ 83 \mathrm{M}$ to process waste at one site vs. $\$ 41 \mathrm{M}$ at each site under Options 1 and 2.

(5) Previous INEL comments have questioned the $\$ 41 \mathrm{M}$ figure for our processing costs. Our estimate to process both the SRP and Hanford Waste is \$46.1M. This includes costs to examine the waste at SWEPP, process in PREPP, and reexamine in SWEPP.

The term "positive cost impact" seems contradictory given the context of the sentence. For Option $c$, do the savings include development costs for GCD?

The cost summary chart indicates savings of \$496M. Also, as previously stated, it should not cost twice as much to process one site's waste under one option as compared to another option where both sites' wastes are being processed.

"Capibility" should be "capability".

(1) Bullet 1 - Couldn't the costs al so be less than predicted?

(2) Bullet 3 - SWEPP is al ready operating and PREPP will be operating in 18 months.

(3) Bullet 8 SWEPP and PREPP are scheduled to process classified wastes. 


\begin{tabular}{|c|c|c|c|c|}
\hline Item & Page & Section & Paragraph & Comment \\
\hline 17 & 19 & $\begin{array}{l}\text { Institutional } \\
\quad \text { Issues }\end{array}$ & $\begin{array}{l}\text { Transporta- } \\
\text { tion }\end{array}$ & $\begin{array}{l}\text { Bullet } 4 \text { - The TRUPACT SARP restricts } \\
\text { free liquids and particulates. The } \\
\text { issue of having a shipping container } \\
\text { for wastes requiring processing } \\
\text { needs to be addressed. Right } \\
\text { now, there is not a container in } \\
\text { place that will meet this need. }\end{array}$ \\
\hline 18 & 29 & Appendix C & 1 & $\begin{array}{l}\text { How can the overall cost per } \\
\text { cubic foot not increase if you } \\
\text { are significantly increasing } \\
\text { the number of required trips } \\
\text { by using overpacks? The shipping } \\
\text { cost is a majority of the trans- } \\
\text { portation costs. }\end{array}$ \\
\hline 19 & 31 & Appendix D & 1 & $\begin{array}{l}\text { Why does SRP need a shielded } \\
\text { backhoe and cask to handle } \\
\text { CH-TRU wastes? }\end{array}$ \\
\hline 20 & 33 & Table E-1 & 1 & $\begin{array}{l}\text { The Hanford operating cost, under } \\
\text { the SWEPP/PREPP category, shows } \\
\$ 20 M \text { without assay and } \$ 76 M \text { with } \\
\text { assay. The incremental cost } \\
\text { of } \$ 56 M \text { is unreasonable. SWEPP's } \\
\text { operating budget is approximately } \\
\$ 4 M / y e a r \text { to process } 5000-6000 \\
\text { containers/year. Assuming Hanford } \\
\text { could only assay } 5000 \text { containers/year, } \\
\text { this equates to a } 7 \text { year campaign, } \\
\text { based on } 35,000 \text { containers. The } \\
\text { maximum cost should be } \$ 28 M \\
\text { (7 yrs } \times 44 \text { year operating). We do } \\
\text { not understand the reason for this } \\
\text { large discrepancy. }\end{array}$ \\
\hline 21 & 34 & Table E-3 & 1 & $\begin{array}{l}\text { What is the basis for the SRP } \\
\text { estimate of } \$ 234 M \text { for operating } \\
\text { costs? With only } 29,000 \text { packages } \\
\text { to examine, and assuming examination } \\
\text { of } 5000 \text { packages per year based } \\
\text { on SWEPP, this equates to a } 6 \\
\text { year campaign. This makes the } \\
\text { operating costs almost } \$ 40 M / \text { year } \\
\text { which greatly exceeds the annual } \\
\text { combined operating costs for both } \\
\text { SWEPP and PREPP. }\end{array}$ \\
\hline
\end{tabular}



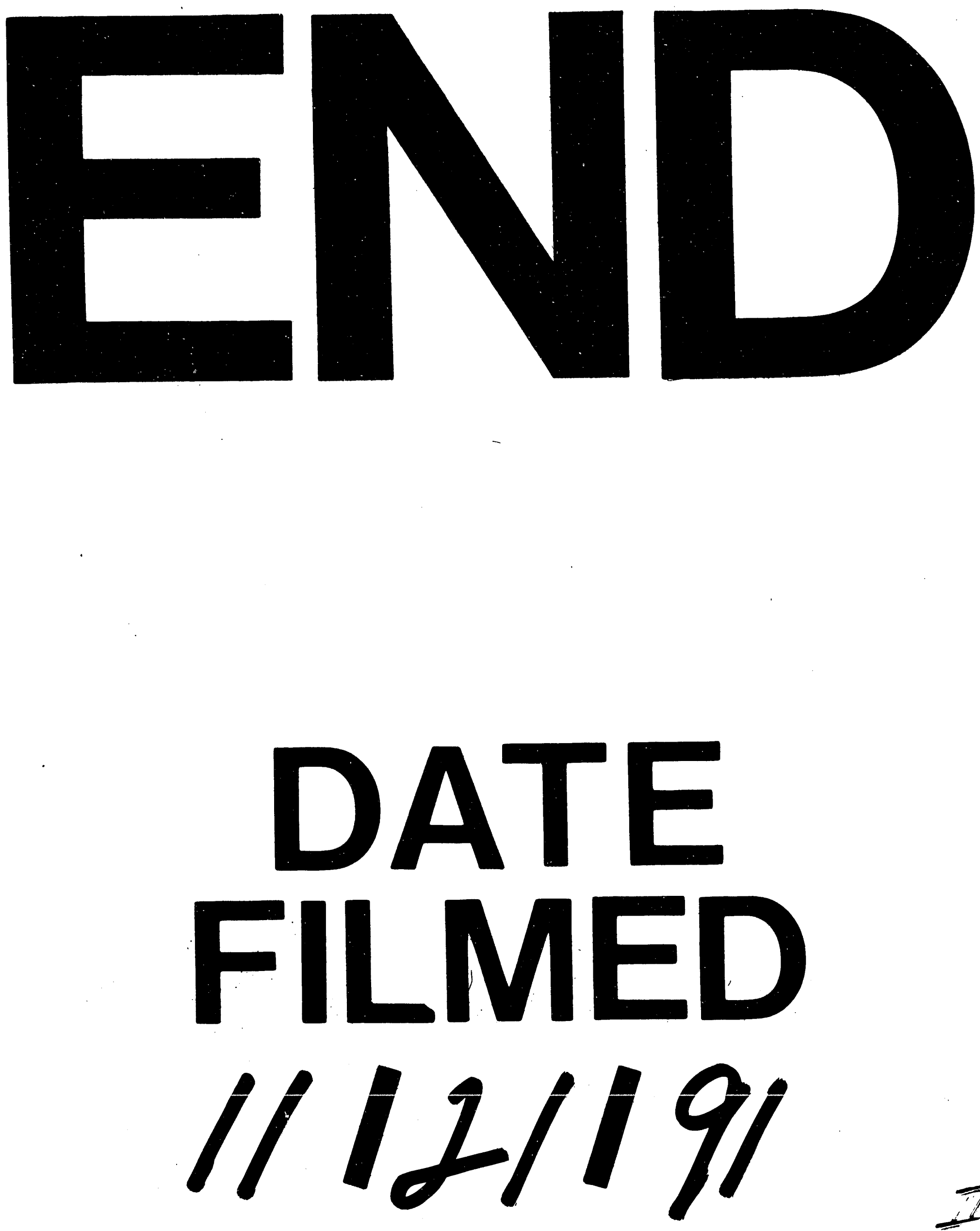

II 


$$
\longrightarrow
$$

